\title{
INTERPLAY BETWEEN ENERGY LIMITATION AND NUTRITIONAL DEFICIENCY: EMPIRICAL DATA AND FOOD WEB MODELS
}

\author{
Ursula Gaedke, ${ }^{1,3}$ Silke Hochstädter, ${ }^{1}$ And Dietmar Straile ${ }^{2}$ \\ ${ }^{1}$ Institut für Biochemie und Biologie, Universität Potsdam, D-14415 Potsdam, Germany \\ ${ }^{2}$ Limnologisches Institut, Universität Konstanz, D-78457 Konstanz, Germany
}

\begin{abstract}
Food quality may play an important role in consumer population dynamics. The frequently large differences in elemental and biochemical composition observed between autotrophs and their grazers suggest that food quality may be of particular importance for herbivores. Under nutrient-depleted conditions the carbon-to-nutrient ratios of autotrophs can increase to such an extent that consumers become nutrient rather than energy limited. Estimating the importance of this effect in situ in pelagic food webs is complicated by the omnivory of many consumers and by rapid nutrient recycling. Isolated predatorprey studies inadequately represent this interaction; instead, an ecosystem perspective is required. We used seven years of data from large, deep Lake Constance to develop seasonally resolved flux models of the pelagic food web and analyzed the balance between energy and nutrient constraints. The carbon (C) and phosphorus (P) flows were simultaneously quantified and balanced. $\mathrm{C}$ represented food quantity/energy. $\mathrm{P}$ was taken as a surrogate of food quality, because algal $\mathrm{C}: \mathrm{P}$ ratios exceeded the threshold above which $\mathrm{P}$ limitation of herbivores is predicted by stoichiometric theory throughout summer and autumn.

Primary production exceeded bacterial $\mathrm{C}$ production by a factor of 3 , but autotrophs and bacteria took up approximately equal amounts of $\mathrm{P}$ during summer and autumn. As a consequence, the $\mathrm{C}$ and $\mathrm{P}$ supplies of suspension-feeding zooplankton were decoupled: Consumer $\mathrm{C}$ demands were largely met by phytoplankton whereas $\mathrm{P}$ was mostly obtained from bacteria and their protist predators. The degree of consumer P deficiency varied according to supplementation of their algal diet with P-enriched bacteria or bacterivores. This favored the occurrence of omnivores, i.e., organisms that minimized P deficiencies at the cost of enhanced energy limitation. In contrast with previous perceptions, $\mathrm{P}$ remineralization during P-depleted summer conditions was dominated by bacterivorous flagellates, carnivorous crustaceans, and fish, which fed on prey with an elemental composition similar to their own, whereas herbivores contributed only $30 \%$ of $\mathrm{P}$ cycling despite their large biomass and $\mathrm{C}$ production. Our results suggested a co-limitation of predominantly herbivorous consumers by $\mathrm{C}$ and $\mathrm{P}$ and a mutual dependence of the two types of deficiency at the individual and system level. This pattern is not specific to pelagic systems but appears to be applicable across ecosystem types.
\end{abstract}

Key words: C:P ratio; elemental composition; energetics; energy cf. nutrient limitation; food quality; food web, pelagic; flux models, mass balanced; Lake Constance (Europe); microbial loop; nutrient remineralization; stoichiometric theory.

\section{INTRODUCTION}

The lack of knowledge about food quality is increasingly recognized as a bottleneck in the understanding of food web functioning (Sterner and Hessen 1994, Anderson and Pond 2000). This holds especially true for herbivores owing to the frequently large differences in the elemental and biochemical composition between autotrophs and their consumers (Hessen 1990, 1997, Elser and Hassett 1994). Macronutrients such as phosphorus were recently identified as potential growthlimiting factors for herbivores (Urabe et al. 1997). This implies that understanding trophic interactions in nutrient-limited ecosystems demands a balanced knowledge of the fluxes of both the energy and the nutrients

Manuscript received 17 November 2000; revised 12 June 2001; accepted 18 June 2001.

${ }^{3}$ E-mail: gaedke@rz.uni-potsdam.de
(Reiners 1986, Andersen 1997). However, elaborate models that explicitly consider multiple commodities are still rare (e.g., Baretta et al. 1995, Ulanowicz and Baird 1999).

Analyzing the potential nutrient deficiency of herbivores and its consequences at the system level in pelagic food webs is complicated by the occurrence of omnivorous rather than strictly herbivorous suspension feeders. Omnivores select their food largely according to size and show little discrimination between autotrophs and heterotrophs. This implies (1) that the entire food web, including the microbial loop, has to be considered in the analysis, and (2) that the relative contribution of autotrophic and bacterial production to the carbon (C) and phosphorus (P) supply of larger consumers is difficult to assess (Vadstein et al. 1993, Hessen 1997).

According to stoichiometric theory, nutrient cycling, 
zooplankton growth, and competition among grazer species are tightly coupled with resource nutrient ratios (Sterner 1990, Sterner and Hessen 1994, Elser et al. 1996, Hessen 1997). Stoichiometric models enable us to calculate the threshold value, $Q_{\mathrm{C}: \mathrm{P}}^{*}$, of the C:P ratio of the prey above which predator growth is limited by an elemental deficiency rather than by energy per se. $Q_{\mathrm{C}: \mathrm{P}}^{*}$ depends on the elemental composition of the consumer and the diet, as well as on the growth efficiency of the consumer with respect to carbon and nutrients (Urabe and Watanabe 1992, Sterner and Hessen 1994, Sterner 1997). Stoichiometric theory has been tested successfully using laboratory systems comprising individual algal species or natural seston as resource and single zooplankton species as consumers (DeMott et al. 1998, Sterner et al. 1998, DeMott and Gulati 1999). Our study extended these investigations by placing individual trophic interactions in a food web context, including the microbial loop and the process of remineralization.

We used a computer algorithm (Hart et al. 1997) based on the inverse approach of Klepper and van de Kamer (1987) and Stone et al. (1993) to establish quantitative food web models that were simultaneously balanced in units of $\mathrm{C}$ and $\mathrm{P}$. These techniques allowed us to account systematically for the inevitable variability and uncertainties introduced by both measurements and assumptions. The model fully incorporates appropriate stoichiometric constraints (Elser and Urabe 1999) while simultaneously providing high food web resolution. That is, within the nonpredatory zooplankton a nutritional gradient is apparent, ranging from predominantly algivorous to more omnivorous consumer groups (i.e., ciliates : rotifers : suspension-feeding crustaceans). Thus, our model connected the bioenergetics of a pelagic community with the complex feedback mechanisms linking grazer and algal nutrient content (Elser et al. 1996) in order to study the balance between energy and nutrient limitation from an ecosystem perspective.

The present model was based on long-term in situ measurements. It builds upon earlier investigations of seasonally resolved, balanced $\mathrm{C}$ flow diagrams elucidating the flow of energy and the trophic structure of the pelagic food web of Lake Constance (Gaedke and Straile 1994a, Straile 1998). These studies revealed a very tight balance between primary production and the cumulative $\mathrm{C}$ demands of all consumers in summer and autumn, suggesting energy-limited growth of herbivores and carnivores, and high trophic-transfer efficiencies (Gaedke and Straile 1994b).

Phosphorus is the dominant limiting macronutrient in large, deep Lake Constance (Güde et al. 1998). Measured $\mathrm{C}: \mathrm{P}$ ratios of phytoplankton and bacteria varied greatly throughout the season. Their values indicated severe $\mathrm{P}$ limitation of algal production during summer and autumn (Hochstädter 2000). During summer stratification, algal C:P ratios ( $\geq 550: 1$, molar) were $4-5$ times higher than those of their consumers and clearly exceeded $Q_{\mathrm{C}: \mathrm{P}}^{*}$ (approximately 250:1 on average). This restricts the maximum $\mathrm{C}$ gross growth efficiency for strictly algivorous consumers to between $20 \%$ and $25 \%$, which is below their physiological maximum (Straile 1997), and suggests P limitation. Hence, we may hypothesize a complex interplay between $\mathrm{C}$ and $\mathrm{P}$ limitation of opportunistically feeding herbivores/ omnivores. Interestingly, constraints imposed by food quantity (C) and quality (P) are not independent from each other in our system as the latter may be reduced by a more selective feeding mode on valuable food items. This is, however, likely to reduce the overall energy intake.

We aimed for an integrated consideration of bioenergetic and nutrient constraints because so far these two schools of thought have developed largely separately from each other (but see Sterner 1997, Anderson and Pond 2000). More specifically,

1) We provide a seasonally resolved, quantitative overview of the $\mathrm{C}$ and $\mathrm{P}$ standing stocks, production, and fluxes within a pelagic food web throughout seven years of investigation;

2) We disentangle the direct and indirect contributions of phytoplankton and bacteria to the $\mathrm{C}$ and $\mathrm{P}$ demands of the various consumer groups and compare them to predictions by stoichiometric theory;

3) We quantify seasonal patterns in the absolute and relative contribution of the different plankton groups to remineralization, that is, to the consumer-driven nutrient recycling and fertilization of the consumer's own prey; and

4) We analyze the strength of and the interplay between $\mathrm{C}$ and $\mathrm{P}$ limitation of consumer production for ciliates, rotifers, and suspension-feeding crustaceans.

Our lake may be regarded as representative for large, open water bodies including marine systems and has been investigated in great detail during the past decades (Bäuerle and Gaedke 1998). Our formulations are not specific to limnetic or marine systems, which makes our results relevant to other ecosystem types as well.

\section{Methods}

\section{Study site}

Upper Lake Constance is a large, deep (maximum depth $=252 \mathrm{~m}$ ), warm-monomictic lake at the northern fringe of the European Alps. Owing to its size (476 $\mathrm{km}^{2}$ ) and a less pronounced stratification than typically found in smaller lakes, Lake Constance has a relatively deep and well-mixed epilimnion and a large pelagic zone. Labile allochthonus imports are presumably of little importance to the energy supply of the plankton, especially in the sampling region. Since 1980 , total $\mathrm{P}$ during winter mixing has declined from $>80$ to $<15$ $\mu \mathrm{g}$ P/L. The trophic state has changed from meso-eutrophic to more oligotrophic conditions (Güde et al. 1998), which is affecting the pelagic community in 
numerous ways (for details see Bäuerle and Gaedke [1998]). During the study period (1987-1993) total P during winter mixing reached 30-58 $\mu \mathrm{g}$ P/L. However, the inorganic $\mathrm{P}$ available to algae and bacteria declined below the detection limit throughout the euphotic zone in summer and autumn and often also in spring. As a consequence, bacterial and algal $\mathrm{C}: \mathrm{P}$ ratios strongly increased from spring to autumn. Typical epilimnetic summer and autumn values totalled 115:1 for bacteria, 500-650:1 for phytoplankton, and 300:1 for seston (Hochstädter 2000). During stratification, plankton production largely depended on the autochthonous regeneration of organismically bound P (Güde and Gries 1998). Nitrate concentrations always remained at a sufficiently high level to allow maximum growth rates (Gaedke 1998). Diatoms were potentially limited by silicate on only a few dates within the sampling period (Gaedke 1998, Güde et al. 1998).

\section{Database}

Sampling was carried out weekly during the growing season and approximately every two weeks in winter, at different depths at a central sampling site $147 \mathrm{~m}$ deep, in the northwestern part of the lake (Überlinger See) from 1987 to 1993 . The abundance of all planktonic organisms was assessed by microscopy using advanced sampling and counting techniques appropriate for the size and fragility of the organisms. Individual body sizes were established by measuring either size frequency distributions (bacteria, heterotrophic flagellates [HF, mostly 1-10 $\mu \mathrm{m}$ length], autotrophic picoplankton [APP]), or average cell volumes of individual taxa (larger phytoplankton, ciliates, rotifers), or the individual length of the organisms (crustaceans). Original measurements of body size were converted to units of $\mathrm{C}$ using measurements from Lake Constance or from the literature (for details see Gaedke [1992]).

The production of phytoplankton $\left({ }^{14} \mathrm{C}\right.$-fixation, $4 \mathrm{~h}$ of incubation), bacteria $\left({ }^{3} \mathrm{H}\right.$-thymidine and ${ }^{14} \mathrm{C}$-leucine incorporation), and heterotrophic flagellates (dilution technique) was measured in situ. For ciliates, estimates were derived from a temperature-dependent allometric relationship for maximum laboratory growth rates (Montagnes et al. 1988). Following recent in situ measurements of ciliate growth in Lake Constance and other lakes (Weisse and Müller 1998), these maximum estimates were reduced by a factor of 5 during the clearwater phase and in summer and autumn to account for food limitation (Gaedke and Straile 1994a, $b$, Straile 1998). The clear-water phase represents a very dynamic period of a few weeks in late May/June when grazer abundance and community grazing rates (mostly dominated by daphnids) reached high, unsustainable levels, leading to a marked decline in the density of phytoplankton and small zooplankton. Production estimates for rotifers and crustaceans were calculated using the "weight-increment method" (Rigler and Downing 1984) in which laboratory-based size-specific and tem- perature-specific growth rates were applied to the in situ abundance and size structure. Egg ratios were calculated for rotifer species carrying their eggs and used as additional production estimates (Pauli 1991). The advantage of using egg ratios is that they account for in situ growth limitations whereas the laboratory growth rates do not (for details see Gaedke and Straile [1994a] and Straile [1998]). Fish production was estimated from fish yield, which is less reliable.

In 1995 the content of particulate $\mathrm{C}$ and $\mathrm{P}$ was measured every two weeks in an unfractionated sample and in five size fractions $(0.2-1 \mu \mathrm{m}, 1-10 \mu \mathrm{m}, 10-30 \mu \mathrm{m}$, $30-100 \mu \mathrm{m},>100 \mu \mathrm{m})$ obtained by filtration over meshes without vacuum pressure (Hochstädter 2000). In each sample the species composition was determined by microscopy. Bacteria and autotrophic picoplankton (APP) contributed $90 \pm 10 \%$ and $10 \pm 10 \%$ (mean \pm $1 \mathrm{SE} ; n=30$ observations) to the abundance in the $0.2-1 \mu \mathrm{m}$ fraction, respectively. Consequently, the C: $P$ ratio of this size fraction was regarded as representative for bacteria. The algal C:P ratio was inferred from the size fractions $1-10 \mu \mathrm{m}, 10-30 \mu \mathrm{m}$, and $30-$ $100 \mu \mathrm{m}$ because they were dominated by autotrophs. The contribution of non-autotrophs to the $\mathrm{C}$ and $\mathrm{P}$ content in these size fractions was derived from their microscopically determined density and their respective $\mathrm{C}: \mathrm{P}$ ratios. The non-algal $\mathrm{C}$ and $\mathrm{P}$ contents were subtracted from the $\mathrm{C}$ and $\mathrm{P}$ content of the individual size fractions to obtain the algal $\mathrm{C}: \mathrm{P}$ ratios. The resulting phytoplankton $\mathrm{C}: \mathrm{P}$ ratios were robust against potential errors in the heterotrophic $\mathrm{C}: \mathrm{P}$ ratios. The $\mathrm{C}: \mathrm{P}$ ratios of the crustaceans were calculated from the $>100-\mu \mathrm{m}$ fraction, which they dominated. A correction for the bacterial and algal $\mathrm{C}$ and $\mathrm{P}$ content in that fraction was performed as described above. The crustaceans C:P ratios showed little variability throughout the season (for details see Hochstädter [2000]). The ratio largely reflected the $\mathrm{C}: \mathrm{P}$ ratio of the daphnids that dominated. $\mathrm{C}: \mathrm{P}$ ratios for rotifers in Lake Constance were determined by Stich (1991). They differed neither significantly from those of the crustaceans nor from the C:P ratios provided in the literature for heterotrophic flagellates (HF) and ciliates (Goldman et al. 1987, Nakano 1994). Consequently, we used the same C:P ratios for all groups of suspension-feeding zooplankton (i.e., HF, ciliates, rotifers, herbivorous crustaceans). The $\mathrm{C}: \mathrm{P}$ ratio of carnivorous zooplankton (cyclopoid copepods and predatory cladocerans) was estimated from laboratory studies (Hessen and Lyche 1991, Stich 1991). The carnivores were consistently underrepresented in the size fraction $>100 \mu \mathrm{m}$, which prevented an in situ determination of their $\mathrm{C}: \mathrm{P}$ ratios. The potential error appears negligible since carnivores were not subject to nutrient deficiency.

The highest algal and bacterial $\mathrm{C}: \mathrm{P}$ ratios measured in 1995 presumably represent upper estimates for the years 1987-1993 owing to the ongoing reoligotrophication process of Lake Constance enforcing summer $\mathrm{P}$ 
TABLE 1. Relative contribution of phytoplankton and bacteria to the food ingested by ciliates.

\begin{tabular}{lcccccc}
\hline \hline & \multicolumn{2}{c}{ Phytoplankton $(\%)$} & & \multicolumn{2}{c}{ Bacteria $(\%)$} \\
\cline { 2 - 3 } \cline { 5 - 6 } & In units of C & In units of P & & In units of C & In units of P \\
\hline Winter $(n=14)$ & $76 \pm 9$ & $62 \pm 12$ & & $4 \pm 2$ & & \\
Spring $(n=14)$ & $90 \pm 4$ & $80 \pm 6$ & & $3 \pm 3$ & $9 \pm 5$ \\
Clear-water phase $(n=6)$ & $82 \pm 4$ & $57 \pm 7$ & & $12 \pm 6$ & $7 \pm 5$ \\
Summer $(n=19)$ & $85 \pm 6$ & $55 \pm 12$ & & $6 \pm 4$ & $29 \pm 13$ \\
Autumn $(n=5)$ & $86 \pm 2$ & $57 \pm 3$ & & $4 \pm 2$ & $19 \pm 9$ \\
\hline
\end{tabular}

Note: Data entries are means $\pm 1 \mathrm{SE} ; n=$ number of time intervals in the category.

depletion (Güde 1991, Güde and Gries 1998). This was accounted for in the model by using bacterial molar C: $\mathrm{P}$ ratios of between 50:1 in winter (no $\mathrm{P}$ depletion) and 130:1 in summer (most severe $\mathrm{P}$ depletion; measured range 50-150:1 in 1995). In the default setting, molar algal C:P ratios in the model ranged from 130:1 in winter and 520:1 in midsummer (measured range 130$775: 1$ during the different seasonal phases). C:P ratios were changed in a sensitivity analysis to explore potential consequences of, for example, further reoligotrophication. The molar C:P ratios for the other plankton groups were kept constant throughout the year at 100: 1 for HF, ciliates, rotifers, herbivorous crustaceans, and fish, and at 115:1 for carnivorous crustaceans. Hence, we do not consider potential species-specific differences in C:P ratios in our model (but see Discussion: Remineralization, below, for sensitivity analyses).

\section{Model food web structure}

In the flow model all pelagic organisms were allocated to one of the following eight compartments: free-living and attached bacteria, phytoplankton including autotrophic picoplankton (APP), heterotrophic flagellates (HF), ciliates, rotifers, predominantly herbivorous crustaceans, predominantly zooplanktivorous crustaceans, and planktivorous pelagic fish. Additionally, a ninth, nonliving compartment accounted for the dead particulate and dissolved organic matter and inorganic $\mathrm{P}$.

In our (model) system, the ciliate compartment was dominated by algivorous species throughout the year, especially in spring. The species constituting the rotifer and herbivorous crustacean compartment were on average more omnivorous. They received $\sim 1.5$ times as much $\mathrm{C}$ and $\mathrm{P}$ from non-algal food sources (bacteria, HF, ciliates, rotifers) as the ciliate compartment (Table 1, Fig. 4). During the study period, daphnids (Daphnia hyalina and D. galeata) constituted $78-86 \%$ of the biomass of the herbivorous crustacean compartment during the clear-water phase, in summer and autumn. The remaining fraction of the biomass was mostly attributable to the calanoid copepod Eudiaptomus. The third suspension-feeding crustacean species, Bosmina, was quantitatively of minor importance. The compartment containing predominantly carnivorous crustaceans comprised the cyclopoid copepods, including their algivorous juveniles, which dominate until June, and the strictly predatory cladocerans Leptodora kindtii and Bythotrephes longimanus, which develop in summer.

The production measurements or estimates were the most important source of information for the flux estimates between the individual compartments. Allocation of prey production to omnivorous predators was derived from the relative share of each predator to total predator production, unless experimental evidence suggested a different diet composition (Gaedke and Straile 1994a, Straile 1998). Dark respiration of phytoplankton was taken as $20 \%$ of primary production (Fahnenstiel and Scavia 1987). Bacterial respiration was calculated as the difference between consumption and production since excretion of organic compounds was regarded as negligible. To balance the flux charts, bacterial consumption had to equal the total egestion of the other compartments minus sedimentation. Thus, bacterial growth efficiency was not a model input but was calculated as the quotient between measured bacterial production and calculated bacterial ingestion. Thus, bacterial growth efficiency could be used as an additional consistency check for the flux charts. Generally, bacterial growth efficiency varied between 5 and $35 \%$ and is therefore in good agreement with recent in situ estimates and measurements made of bacterial growth efficiency (del Giorgio and Cole 1998). The respiration rates of other heterotrophs were set equal to the respective production rates, which implied net growth efficiencies of 0.5 . This simple assumption acknowledges the high contribution of the specific dynamic action to total respiration in plankton organisms and avoids potential errors arising when combining production and respiration measurements conducted by different research groups (for details see Gaedke and Straile [1994a] and Straile [1998] and literature cited therein).

The release of any particulate or dissolved $\mathrm{C}$ and $\mathrm{P}$ by heterotrophs is referred to as "egestion" in the following text. Egestion was calculated as the difference between ingestion and the sum of production and respiration. Based on measurements conducted in Lake Constance, exudation by phytoplankton varied seasonally between 5 and $15 \%$ of primary production in the model. Sedimentation of larger diatoms amounted to $10 \%$ per day (Güde and Gries 1998), and bacterial lysis by phage infection to $10 \%$ of bacterial production (Hennes and Simon 1995). 
P fluxes were estimated by converting the respective mass-balanced C flux charts (Gaedke and Straile 1994a, Straile 1998) into units of $P$ using the measured C:P ratios as described in Database, above (Hochstädter 2000). The C flux diagrams could be balanced only after a reduction in the production estimate of herbivorous crustaceans during the clear-water phases, i.e., the period of strongest food depletion, and the abovementioned adjustment of ciliate production to in situ conditions. The C:P ratio of each prey compartment was used to estimate $\mathrm{P}$ fluxes to consumer compartments, while the net $\mathrm{P}$ uptake by phytoplankton and bacteria was obtained from the algal and bacterial $\mathrm{C}$ : $\mathrm{P}$ ratio and their respective net $\mathrm{C}$ production. Egestion of $\mathrm{P}$ was calculated as the difference between nutrient input into a compartment and its nutrient outflow and was allocated to the nonliving compartment.

Subsequently we attempted to balance the mass-flow diagrams based on these preliminary flux estimates and the assumption that the maximum gross growth efficiency (i.e., the ratio between production and ingestion) of consumer compartments was restricted to $33 \%$ in units of C (Gaedke and Straile 1994b, Straile 1997) and to $80 \%$ in units of P (Hessen and Andersen 1990). We took these values as defaults in our model even though they are lower than some maximum growth efficiencies obtained in laboratory studies (Olsen et al. 1986) because processes such as sloppy feeding and uptake of nondigestible organisms or body parts were not explicitly considered in the model. These processes reduce growth efficiency and may play a substantial role in natural systems. To account for these loss factors, we used gross growth efficiencies below the highest observed under optimal conditions in the laboratory in the model. We assessed the sensitivity of our results to these assumptions.

The inputs and outputs of both $\mathrm{C}$ and $\mathrm{P}$ were balanced around each compartment (i.e., the sum of all inputs matched the sum of all loss terms in both units of $\mathrm{C}$ and $\mathrm{P}$ ), and to the entire system (e.g., primary production had to balance respiration and sedimentation). This led to a highly overdetermined set of equations, i.e., the number of equations was much larger than the number of free parameters. The set of equations was solved using software developed by Hart et al. (1997), which was based on an inverse approach (Klepper and van de Kamer 1987, Stone et al. 1993) that kept the balanced quantitative food web models closest to their initial estimates. This was achieved by minimizing as the "objective function" the distance between any hypothetical flux chart and the known initial flux estimates that satisfied all the constraints as represented by the actual measurements and the assumptions described above. Differences in the uncertainties and variability among the initial flux estimates were considered by systematically defining an upper and lower boundary for each flux (Stone et al. 1993). Relatively narrow boundaries were imposed upon well-established fluxes whereas less well-known fluxes were assigned broader limits. That is, whenever the initial flux estimates had to be modified in order to fulfill mass balance or other constraints, flux estimates known with greater confidence were allowed to change to a lesser degree than those supported by less reliable data. The degree of flexibility under which the program could search for feasible solutions was under the control of the user (for details see Hart et al. [1997]). This feature allowed us to search within ecologically reasonable boundaries for diet compositions of the individual plankton compartments that balanced $\mathrm{C}$ and $\mathrm{P}$ demands. In this way the program mimicked the opportunistic feeding behavior exhibited by and the positive selection of those species or plankton groups (e.g., favoring bacterivorous ciliates over algivorous ones) that were more capable of exploiting P-rich prey items under P-depleted conditions. Therefore, we are reasonably confident that our model follows the principal behavior of the natural system as closely as possible.

Each of the seven years of investigation was subdivided into 7-10 different time intervals to track seasonal changes in the balanced flux charts. The beginning and end of each time interval, lasting between 14 to $102 \mathrm{~d}$ and comprising $2-12$ sampling dates, were not fixed to certain dates but determined according to changes in the numerous physical, chemical, and biological parameters during each year (for details see Straile [1998]). Temporal biomass changes within time intervals were accounted for in the model equations (see Gaedke and Straile 1994a).

\section{Results}

\section{Standing stocks and production}

The contribution of the individual compartments of organisms to total pelagic biomass varied strongly during the season and moderately among years, depending on the commodity under consideration (Fig. 1a). The latter effect was most pronounced for autotrophs, which contributed $25 \%$ of the total $\mathrm{C}$ biomass but only $10 \%$ of the $\mathrm{P}$ biomass on average, annually. In contrast, bacteria contributed a higher proportion to the total biomass in units of $\mathrm{P}$ than in $\mathrm{C}(18 \%$ as compared with $12 \%)$. The share of predominantly herbivorous organisms (ciliates, rotifers, and herbivorous crustaceans) was largely independent of the commodity ( $38 \%$ in C, $40 \%$ in P) (Fig. 1a).

With regard to community production, the high contribution of autotrophs to total pelagic production accentuated differences between both commodities. The algal contribution amounted to $70 \%$ in units of $\mathrm{C}$ but only $20-50 \%$ in units of P (Fig. 1b) in this autochthonous model food web. As a consequence, bacterial and herbivorous production gained in relative importance in terms of $\mathrm{P}$ as compared with $\mathrm{C}$.

The ratio between bacterial and primary $\mathrm{C}$ production to a large extent determines the relative importance 

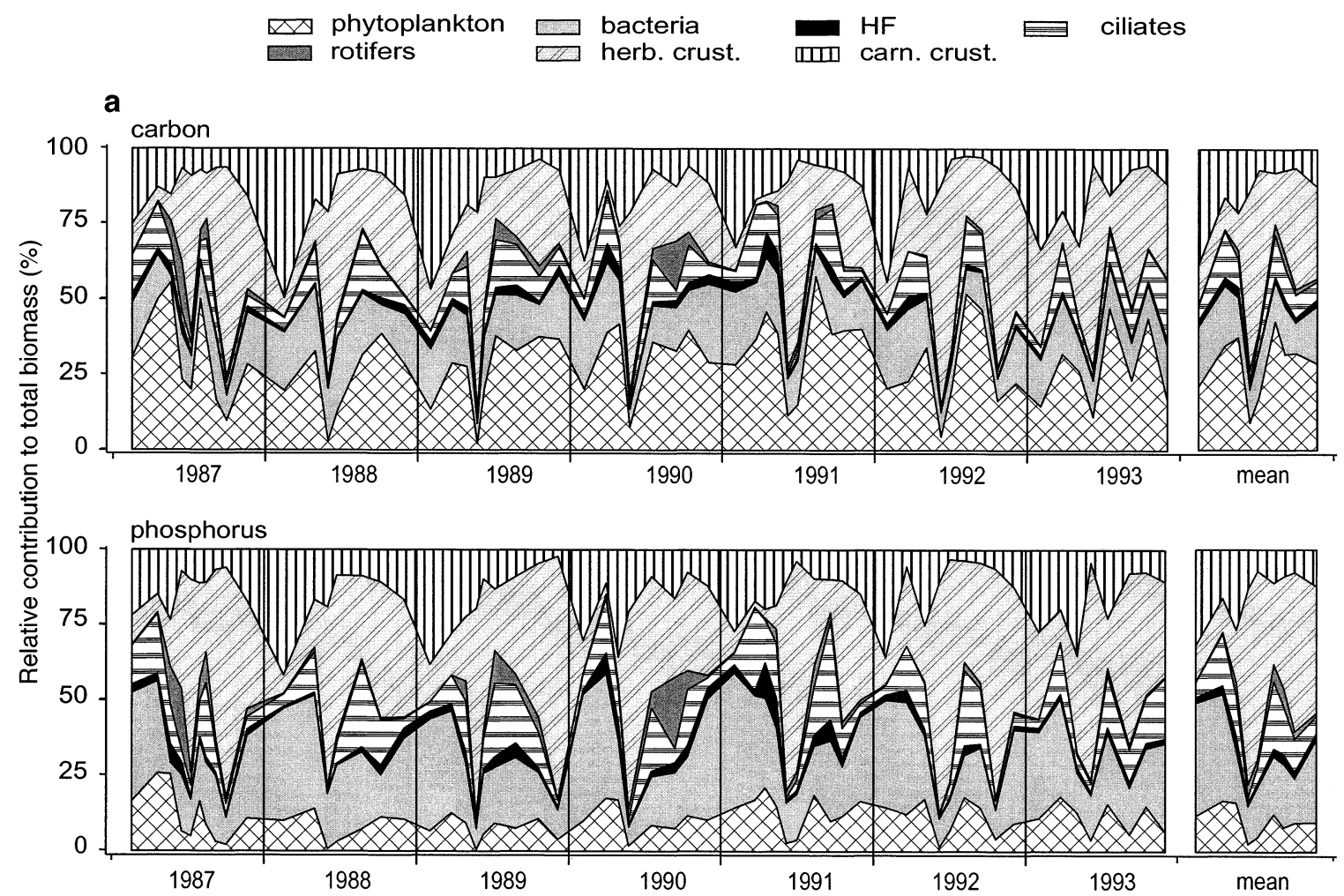

b
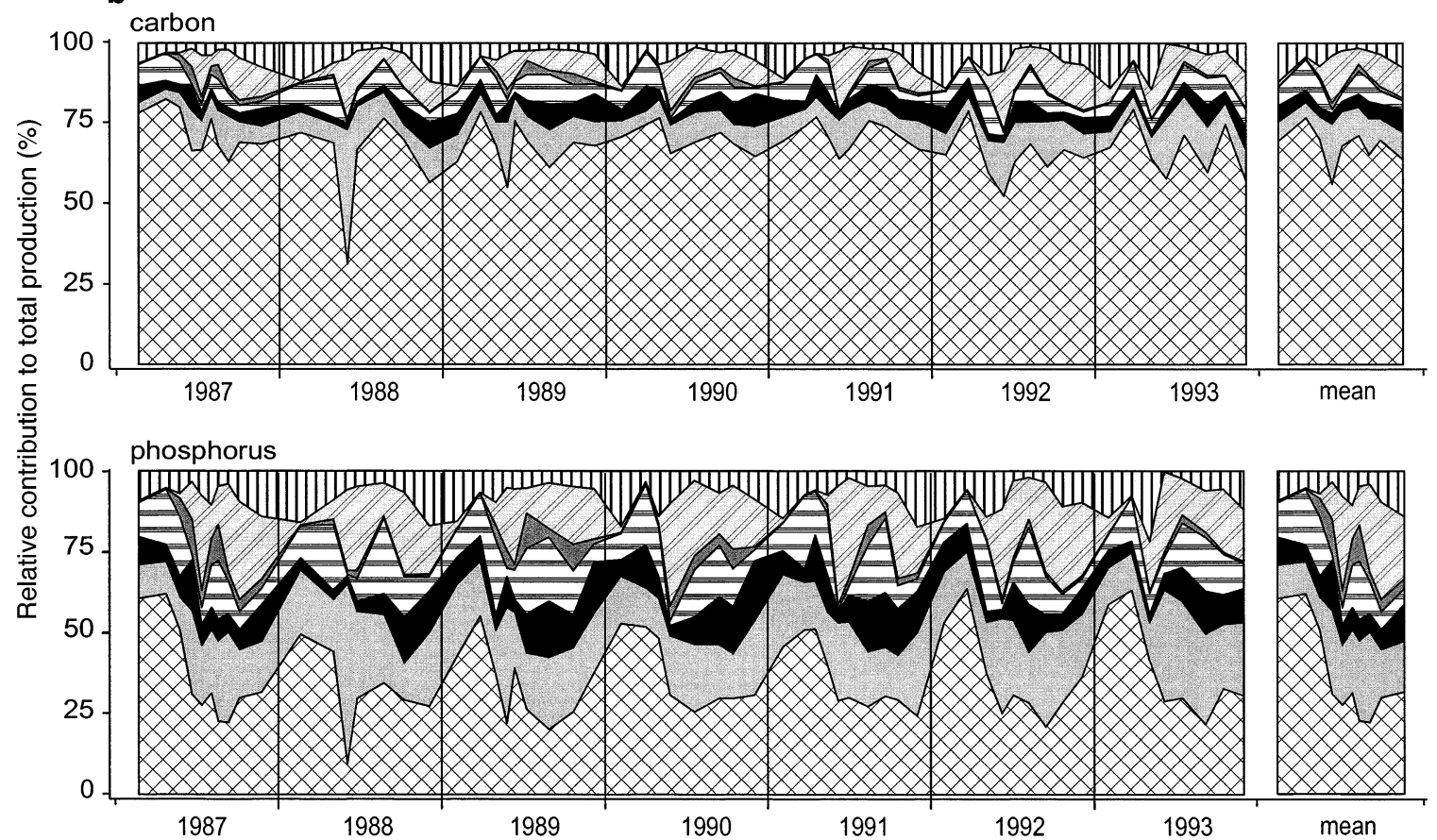

FIG. 1. Seasonal and interannual variability in the relative contribution of the individual plankton groups to (a) total biomass and (b) total production, quantified in units of $\mathrm{C}$ (upper panel) and $\mathrm{P}$ (lower panel). Phytoplankton constituted a major fraction of the $\mathrm{C}$ biomass and $\mathrm{C}$ production but was of less importance with respect to $\mathrm{P}$. To improve the clarity of the figure, a linear interpolation was used between consecutive time intervals and fish was omitted (but not from the model). Abbreviations used in key: herb. crust., herbaceous crustaceans; carn. crust., carnivorous crustaceans; HF, heterotrophic flagellates. 


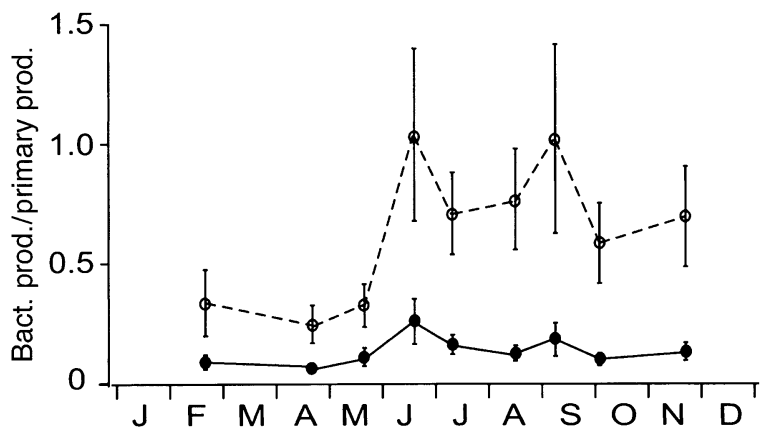

FIG. 2. Seasonal variation of the ratio between bacterial and primary production in units of $\mathrm{C}$ (solid line and circles) and $\mathrm{P}$ (dashed line and open circles). Vertical bars indicate $\pm 1 \mathrm{SD}$ for the seven years of investigation.

of the microbial community to the $\mathrm{C}$ supply of larger zooplankton. The ratio varied little throughout most of the year $(0.12 \pm 0.03)$ but increased during the clearwater phase $(0.28 \pm 0.11)$ (means $\pm 1 \mathrm{SE}$ ) (Fig. 2). In units of $\mathrm{P}$ the ratio between bacterial and primary production was greater, amounting to 0.47 and 0.23 in winter and spring and to between 0.6 and 1.0 in summer and autumn, respectively. This relatively low P uptake/ production of phytoplankton as compared with that of bacteria in the second half of the year is consistent with their relatively low contribution to total $\mathrm{P}$ production $(\sim 30 \%)$ during this period (Fig. 1b).

\section{$C$ and $P$ fluxes}

As a consequence of the different and temporally variable $\mathrm{P}$ content of bacteria and phytoplankton, the absolute and relative importance of the different fluxes within the system depended on the unit ( $\mathrm{C}$ or $\mathrm{P})$ under consideration and varied throughout the season, especially in units of $\mathrm{P}$ (Fig. 3). C fluxes were dominated by autotrophs and herbivores, and by the $\mathrm{C}$ uptake and respiration of bacteria. The $\mathrm{C}$ transfer from the microbial loop to larger consumers increased from spring to summer but remained of minor importance owing to the losses through respiration and egestion. So too did the $\mathrm{C}$ fluxes of organisms at the higher trophic levels. $\mathrm{C}$ egestion was dominated by the herbivores throughout the year, particularly in spring.

$\mathrm{P}$ remineralization by carnivores and heterotrophic flagellates $(\mathrm{HF})$ was high in relation to $\mathrm{C}$, as were the

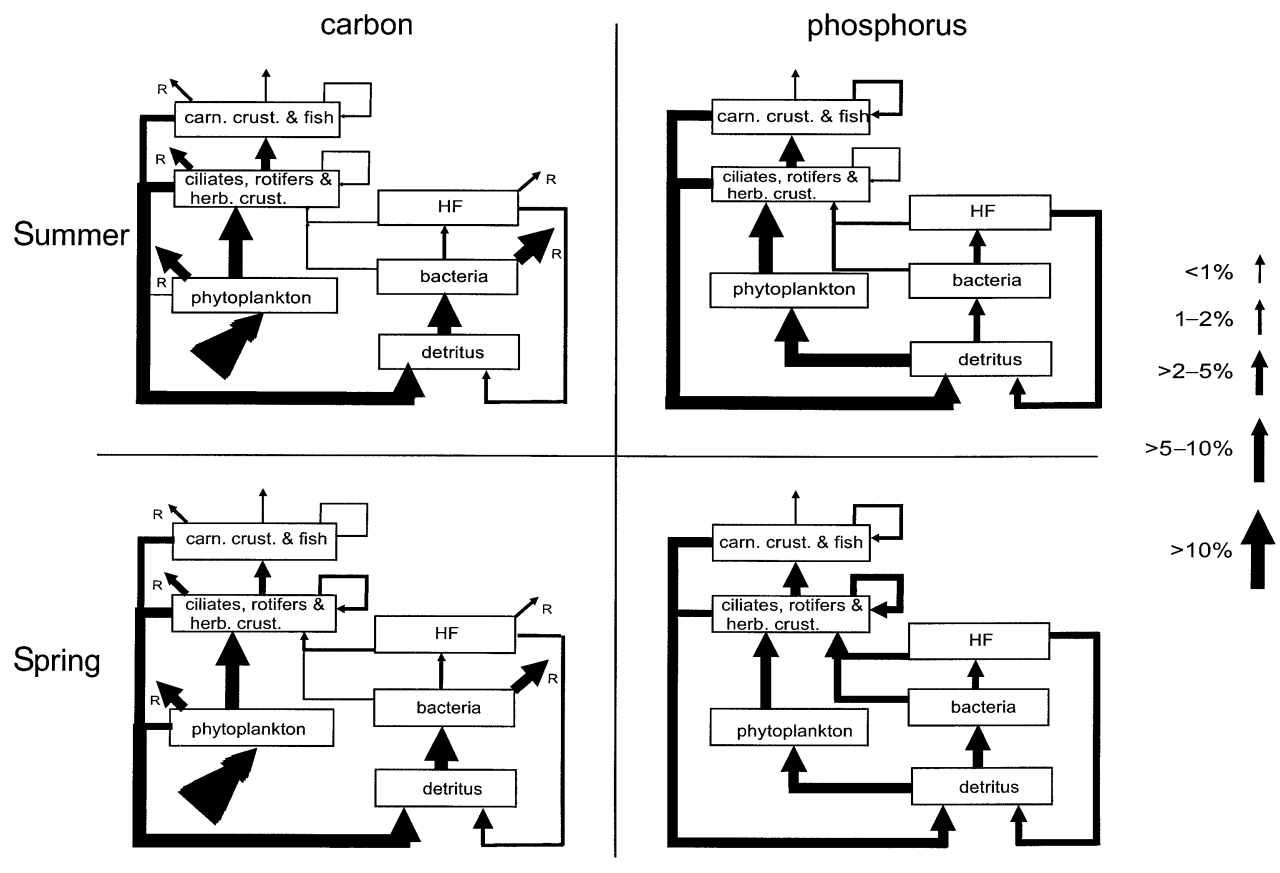

Fig. 3

FIG. 3. Semi-quantitative C (left) and P (right) fluxes in the pelagic food web of Lake Constance in spring (upper panels) and summer (lower panels). C represents food quantity (energy), and P the food quality. In spring, phytoplankton and bacteria have considerably lower C:P ratios (i.e., a higher food quality) than in summer when ambient $\mathrm{P}$ concentrations are depleted. The width of the arrows reflects the quantity of the fluxes (percentage of the total system throughput, i.e., the sum of all fluxes within the system); $\mathrm{R}=$ respiration, carn. = carnivorous, herb. = herbivorous, crust. = crustaceans, and $\mathrm{HF}=$ heterotrophic flagellates. In contrast to the model, ciliates, rotifers, and herbivorous crustaceans are combined here in one box for clarity, as are carnivorous crustaceans and fish. The compartment labeled "detritus" comprises all nonliving dissolved or particulate organic C and inorganic P. Some minor fluxes such as sedimentation and the grazing of HF and carnivorous crustaceans on phytoplankton are not shown in the figure for the sake of clarity but are accounted for in the computations. This may give the impression of a slight imbalance between compartments in a few cases. 
P flows within and from the microbial loop to larger consumers (Fig. 3). These differences between the C and $\mathrm{P}$ flow diagrams were more pronounced in summer than in spring owing to the greater differences in $\mathrm{C}: \mathrm{P}$ ratios between consumers and their prey. In summer, bacteria and HF contributed significantly to the P supply of suspension-feeding zooplankton, as did feeding interactions within this group of plankton comprised of ciliates, rotifers, and crustaceans. In terms of C, these trophic interactions remained of minor quantitative importance throughout the year (Fig. 3).

The equations underlying the balanced flow model were grossly overdetermined as we set boundaries on the values for gross and net growth efficiencies, the variability in the diet compositions and the $\mathrm{C}: \mathrm{P}$ ratios, in addition to the production estimates. Hence, the number of equations greatly exceeded the number of free parameters. Nevertheless, balanced flux charts for all winter and springtime intervals showed that $\mathrm{P}$ did not impose additional constraints to $\mathrm{C}$ limitation during those periods. In contrast, such balancing was impossible during midsummer and autumn, unless production of the predominantly herbivorous zooplankton (i.e., ciliates, rotifers, and herbivorous crustaceans) was reduced by $20 \%$. Otherwise herbivore $\mathrm{P}$ demands exceeded the combined $\mathrm{P}$ production of bacteria and autotrophs. Hence, the model suggested that the predominantly laboratory-derived growth-rate estimates were too high for the ambient in situ resource supply (quantity and/or quality), and that the gross growth efficiency of herbivores was constrained by $\mathrm{P}$ rather than $\mathrm{C}$. Reducing only ciliate production was not sufficient to balance the $\mathrm{P}$ demands of herbivores with the $\mathrm{P}$ uptake by algae and bacteria because this led to a shortage of non-algal, P-rich food for rotifers and crustaceans. Thus, subsequent considerations were based on the balanced flow charts with an herbivorous production reduced by $20 \%$ in summer and early autumn.

\section{Contribution of phytoplankton and bacteria to consumer $C$ and $P$ demands}

An understanding of nutrient limitation and recycling demands a detailed knowledge of the $\mathrm{C}$ and $\mathrm{P}$ sources of the suspension-feeding zooplankton. Such information can be obtained by analyzing changes in their seasonal diet compositions. In winter and spring, phytoplankton delivered $70-85 \%$ of the $\mathrm{C}$ and $40-70 \%$ of the $\mathrm{P}$ ingested by predominantly herbivorous zooplankton, whereas bacteria contributed only $5-10 \%$ of both commodities (Fig. 4a, Table 1). In contrast, herbivores obtained $\sim 60 \%$ of their $\mathrm{P}$ demands from bacteria, HF, and ciliates, but only $35 \%$ from autotrophs, during summer and autumn. The autotrophs, however, continued to supply $\sim 70 \%$ of the $\mathrm{C}$ whereas the contribution from bacteria and Protozoa amounted to only $25 \%$.

The diet compositions of carnivorous crustaceans exhibited smaller differences between the two commod- ities (Fig. 4b). During winter and spring, the phytoplankton delivered a large proportion of the $\mathrm{C}$ and $\mathrm{P}$ since the juveniles of the dominant crustacean species were largely herbivorous. From the clear-water phase onwards strictly carnivorous species prevailed, preying on food with an elemental composition very similar to their own body tissue. The relative dependency of the carnivorous crustaceans on bacterial production cannot be inferred directly from their diet composition since they did not feed on bacteria. However, because the prey of the carnivorous crustaceans depended on bacterial $\mathrm{P}$, carnivorous crustaceans also relied indirectly on bacterial $\mathrm{P}$ production. To quantify this indirect dependency of carnivores on bacterial $\mathrm{P}$ uptake we used a network-analysis method and computed total-dependency coefficients. In this specific case they quantify any fraction of carnivorous intake that had ever passed through the bacterial compartment (Wulff et al. [1990] and Ulanowicz and Kay [1991] and literature cited therein). These computations revealed that $\mathrm{P}$ originally taken up by bacteria was also essential to cover the $\mathrm{P}$ demands of carnivores (Table 2). Conversely, C (i.e., energy) was almost exclusively supplied via the grazing chain, i.e., by autotrophs and their direct consumers.

\section{Remineralization}

The maximum P-retention ability of the consumers plays an important role for their growth potential and the P remineralization (Andersen 1997, Elser and Urabe 1999). A high $P$ retention implies a high $C$ growth potential of the herbivores at a given $\mathrm{P}$ consumption, but also a lower rate of $\mathrm{P}$ egestion and $\mathrm{P}$ remineralization. The latter may reduce autotrophic and bacterial production and, hence, indirectly consumer production. We analyzed the direct and indirect effects of changes in the maximum P-retention ability on our model results by applying values of 60 and $100 \%$, in addition to our standard value of $80 \%$. Allowing a P-retention ability of up to $100 \%$ was sufficient to completely overcome $\mathrm{P}$ limitation of the predominantly herbivorous consumers in the model during some, but not all, summer and autumn periods. As would be expected, $100 \%$ $\mathrm{P}$ retention caused a reduction of the $\mathrm{P}$ egestion by all herbivores as well as by heterotrophic flagellates. Consequently, the $\mathrm{P}$ available for primary and bacterial production was reduced (Fig. 5). Bacteria and HF were more strongly affected by the reduction of $\mathrm{P}$ recycling than the organisms forming the grazing chain, which obtained larger additional subsidies from the microbial loop. A high $\mathrm{P}$ retention at the lower trophic levels caused longer cycles and a more efficient transfer of $\mathrm{P}$ to the higher trophic levels. This was reflected, e.g., by the unchanged level of $\mathrm{P}$ consumption and egestion by the carnivores despite the overall reduction of $\mathrm{P}$ remineralization and $\mathrm{P}$ uptake at the base of the food web.

A reduction in the maximum consumer P-retention 


$\begin{array}{llll}\square \text { phytoplankton } & \square \text { bacteria } \\ \text { rotifers } & \text { herb. crust. } \square \text { carn. crust. }\end{array}$

a) Diet composition of herbivorous crustaceans
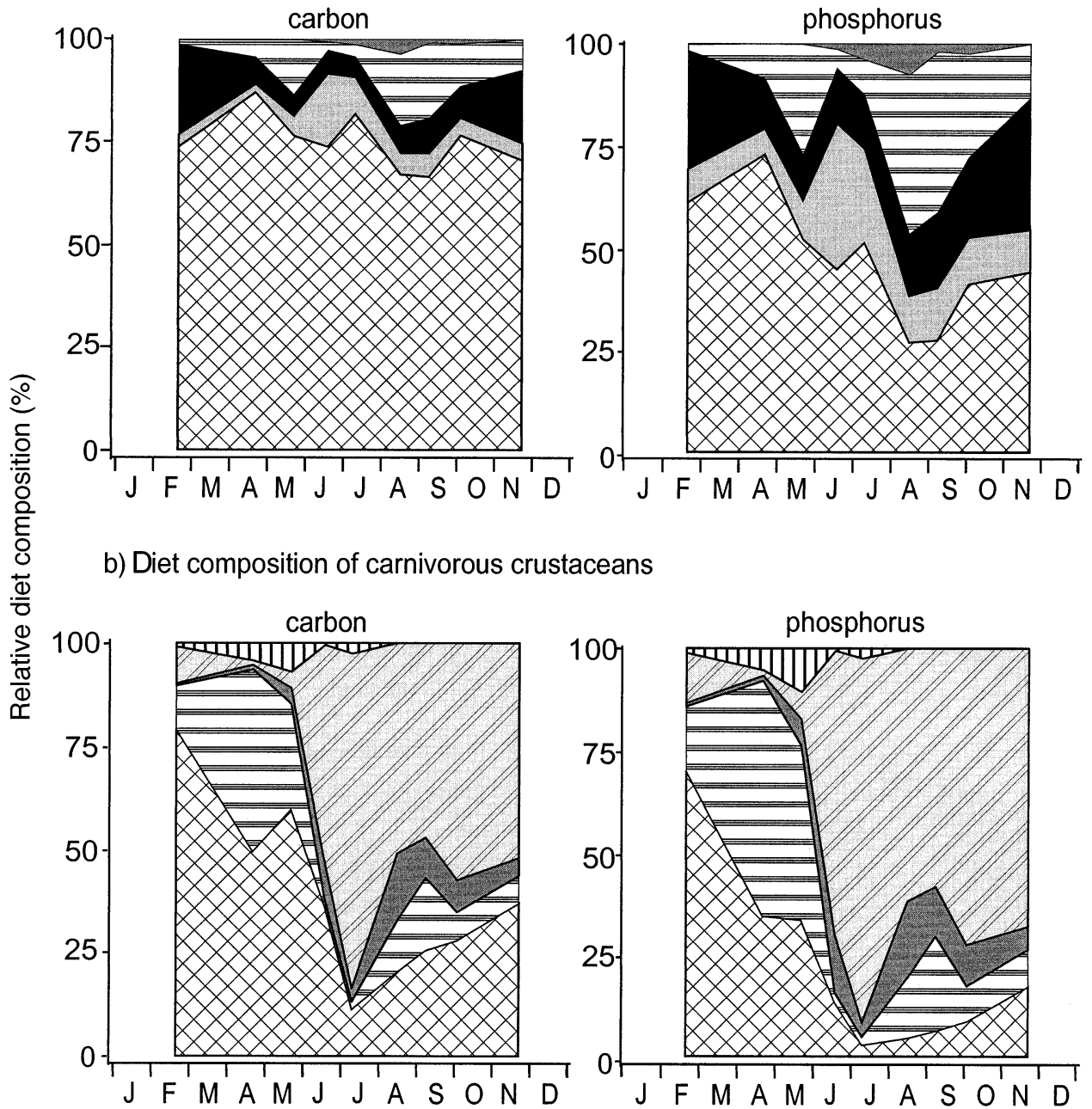
TABLE 2. Total-dependency coefficients of the carnivorous crustaceans on phytoplankton and bacteria.

\begin{tabular}{lcccccc}
\hline \hline & \multicolumn{2}{c}{ Phytoplankton $(\%)$} & & \multicolumn{2}{c}{ Bacteria $(\%)$} \\
\cline { 2 - 3 } \cline { 5 - 6 } \multicolumn{1}{c}{ Season } & In units of C & In units of P & & In units of C & In units of P \\
\hline Winter $(n=14)$ & $92 \pm 6$ & $77 \pm 17$ & & $3 \pm 2$ & $2 \pm 0$ & $22 \pm 8$ \\
Spring $(n=14)$ & $99 \pm 1$ & $95 \pm 3$ & & $2 \pm 2$ & $24 \pm 9$ \\
Clear-water phase $(n=6)$ & $90 \pm 8$ & $69 \pm 12$ & & $10 \pm 4$ & $51 \pm 9$ \\
Summer $(n=19)$ & $90 \pm 12$ & $63 \pm 14$ & & $8 \pm 3$ & $47 \pm 13$ \\
Autumn $(n=6)$ & $96 \pm 2$ & $70 \pm 8$ & & $5 \pm 1$ & $39 \pm 4$ \\
Annual average $(n=7)$ & $96 \pm 2$ & $82 \pm 5$ & & $5 \pm 1$ & $35 \pm 4$ \\
\hline
\end{tabular}

Notes: The coefficients quantify the fraction of the food that had passed through the phytoplankton (left) or bacterial (right) compartment at any stage. They show that the P taken up by bacteria constituted $51 \%$ and $47 \%$ of the $\mathrm{P}$ ingested by carnivorous crustaceans during the clear-water phase and summer, respectively (these are the highest numbers for bacterial contribution). Entries are means $\pm 1 \mathrm{SE} ; n=$ number of time intervals in the category.

$\mathrm{C}: \mathrm{P}$ ratios similar to that of their own biomass throughout the year and consequently egested P-rich material.

The C:P-ratio of matter egested by zooplankton was nonlinearly related to that of their diet in the model (Fig. 7). For diets with molar C:P ratios below 195:1, egesta were enriched in $\mathrm{P}$ owing to the $\mathrm{C}$ losses by respiration when assuming a P-retention ability of $80 \%$. Above this threshold, egesta were increasingly $\mathrm{P}$ depleted as zooplankton selectively concentrated $\mathrm{P}$ into their body tissue. This situation was typical for herbivores, and especially ciliates, in summer (Fig. 7).

The level of $\mathrm{C}$ and $\mathrm{P}$ cycling was determined by the amount and elemental composition of the material egested by the various consumer compartments. The contribution of the different compartments to $\mathrm{P}$ cycling depended on (1) the C:P ratio of their egesta (Fig. 6), (2) their biomass (Fig. 1a), and (3) their mass-specific metabolic rates, which declined allometrically with body size. HF had low biomass but high metabolic rates and high $\mathrm{P}$ concentrations in both the ingested and egested material (Fig. 6). This implies that they had high rates of mass-specific $\mathrm{C}$ and $\mathrm{P}$ releases $(10-15 \mathrm{mg}$ $\mathrm{C} \cdot \mathrm{mg} \mathrm{C}^{-1} \cdot \mathrm{d}^{-1}$ and $\left.0.17-0.36 \mathrm{mg} \mathrm{P} \cdot \mathrm{mg} \mathrm{C}^{-1} \cdot \mathrm{d}^{-1}\right)$ and contributed significantly $(10-20 \%)$ to the $\mathrm{P}$ release (Fig. 8) despite their small biomass (1\% of total biomass). This result is in agreement with measurements conducted in situ at Lake Constance (Jürgens and Güde 1990). Ciliates were characterized by temporarily high biomasses, high mass-specific feeding rates, and a variable and often low $\mathrm{P}$ content in their nutrition and egesta. As a consequence, during spring they released $\sim 18 \mathrm{mg} \mathrm{C} \cdot \mathrm{mg} \mathrm{C}^{-1} \cdot \mathrm{d}^{-1}$ and $0.18 \mathrm{mg} \mathrm{P} \cdot \mathrm{mg} \mathrm{C} \mathrm{C}^{-1} \cdot \mathrm{d}^{-1}$ and retained a share of $37 \%$ of the $\mathrm{P}$ remineralization. During their summer development, ciliate egesta were strongly $\mathrm{P}$ depleted (molar C:P $=580-650: 1,0.03 \mathrm{mg}$ $\mathrm{P} \cdot \mathrm{mg} \mathrm{C}^{-1} \cdot \mathrm{d}^{-1}$ ) and thus contributed only $15 \%$ to $\mathrm{P}$ remineralization despite ciliates contributing $17 \%$ of the total consumer biomass and consuming 45-60\% of phytoplankton primary production. Herbivorous crustaceans represented the largest herbivores. They had consistently low rates of mass-specific $\mathrm{P}$ release $(0.02$ $\mathrm{mg} \mathrm{P} \cdot \mathrm{mg} \mathrm{C}^{-1} \cdot \mathrm{d}^{-1}$ ) that was partially compensated for by a high biomass ( $56 \%$ of all consumers) and moderate $\mathrm{C}: \mathrm{P}$ ratios in the egesta $(250: 1)$. Unexpectedly, carnivorous crustaceans and fish achieved a greater importance for $\mathrm{P}$ mineralization $(40-70 \%$ in summer) than ciliates and herbivorous crustaceans together, despite their lower biomass (27\% of all consumers). The high $\mathrm{P}$ remineralization of carnivores was caused by their relatively high $\mathrm{P}$ release rate $\left(0.15 \mathrm{mg} \mathrm{P} \cdot \mathrm{mg} \mathrm{C}^{-1} \cdot \mathrm{d}^{-1}\right)$, which originated mostly from a high $\mathrm{P}$ content in their nutrition. To summarize, predominantly herbivorous zooplankton released $\sim 70 \%$ of the organic $\mathrm{C}$ but only $15-40 \%$ of the $\mathrm{P}$, whereas the carnivores, together with the bacterivorous flagellates, dominated $\mathrm{P}$ remineralization but were less important with respect to $\mathrm{C}$ (Figs. 3 and 8).

\section{Discussion}

\section{Methods and model assumptions}

Our study delivered a simultaneous quantification of the $\mathrm{C}$ and $\mathrm{P}$ fluxes for an entire pelagic food web. This process demanded a detailed knowledge of biomass, process rates, diet composition, gross and net growth efficiency, and C:P ratio for each living compartment. Due to a large, cooperative program conducted at Lake Constance during 1987-1997, this prerequisite was fulfilled in an unusually comprehensive manner (Bäuerle and Gaedke 1998). However, it cannot be denied that inevitable uncertainties remained in the parameter estimates (cf. Güde and Gries 1998). The surplus of massbalance equations provided us with an opportunity to check the consistency of the numerous measurements and assumptions. For example, for each individual compartment ingestion had to balance the sum of egestion, respiration, and production (given reasonable growth efficiencies), and the total egestion in the food web had to satisfy bacterial demands. By these means the model provides an indication of the quantitative importance of some processes, which are not currently measurable. For most periods during 1987-1993, balanced $\mathrm{C}$ flow charts could be established within the boundary conditions imposed by measured and liter- 

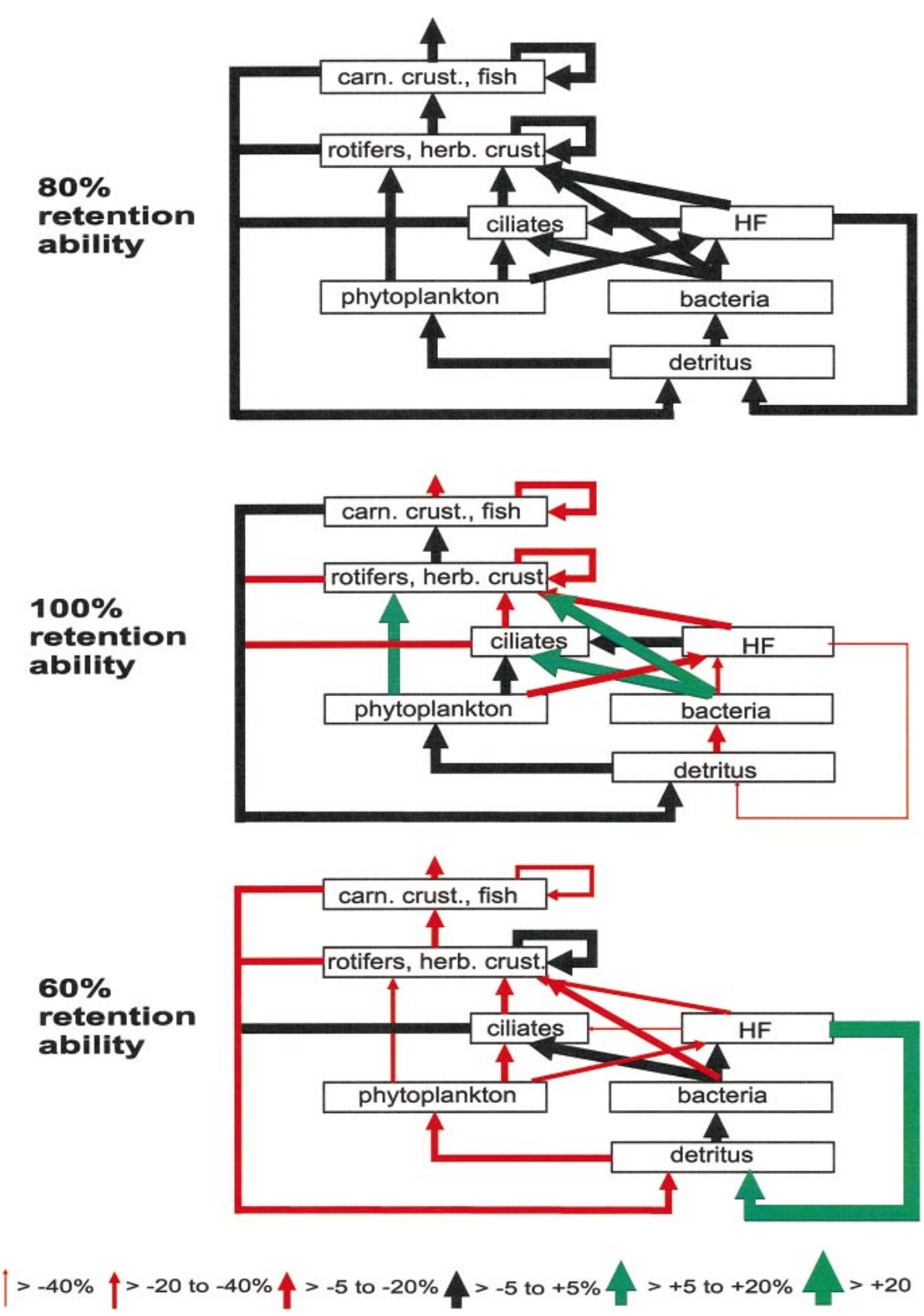

FIG. 5. Impact of the maximum P-retention ability of the consumers on the P fluxes in the pelagic food web model of Lake Constance, balanced in respect to $\mathrm{C}$ and $\mathrm{P}$. The figure depicts the relative changes (not the absolute values) of individual fluxes compared with a P-retention ability of $80 \%$, the standard value in our analysis. The width of the arrows indicates the extent of deviation from the standard value. Upper panel: $80 \%$ P-retention ability; all fluxes were set to $100 \%$ (standard). Middle panel: The P-retention ability was set to $100 \%$. This strongly reduced remineralization by heterotrophic flagellates (HF) and increased the fluxes toward ciliates and crustaceans. Lower panel: The P-retention ability was reduced to $60 \%$, which enhanced remineralization by HF and reduced most $\mathrm{P}$ fluxes at the higher trophic levels and their P recycling. In contrast to the model, rotifers and herbivorous crustaceans (herb. crust.) are combined here in one box for clarity, as are carnivorous crustaceans (carn. crust.) and fish.

ature data, after accounting for potential food limitation of consumer production (Gaedke and Straile 1994a, Straile 1998). In the present study the envelope of balanced flux charts was further constrained by also taking the $\mathrm{P}$ budgets and $\mathrm{C}: \mathrm{P}$ ratios of the different compartments and the entire system into account.

Mass-balanced $\mathrm{C}$ and $\mathrm{P}$ flow charts that were not in conflict with any of our measurements or literature val- 
a) Spring

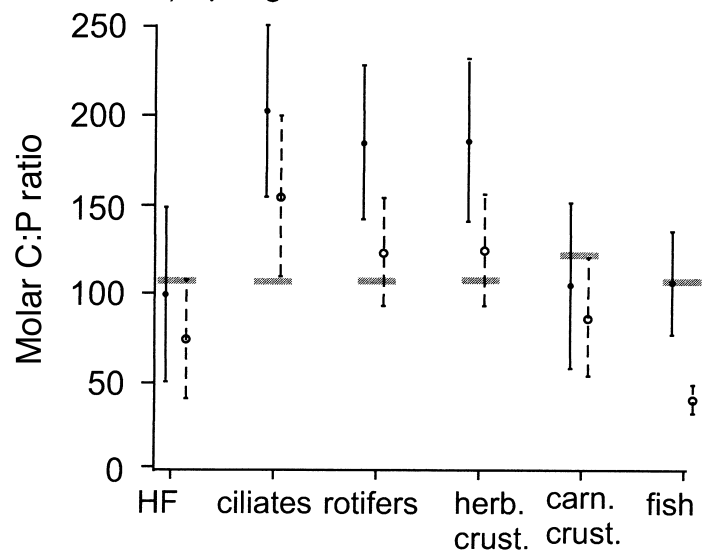

b) Summer

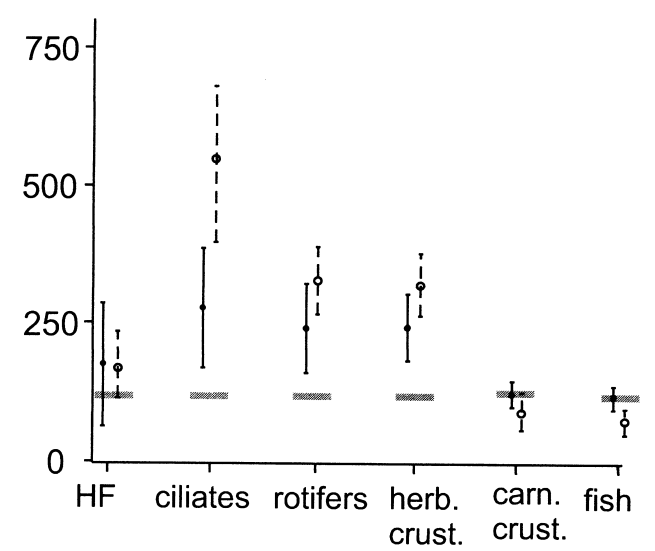

FIG. 6. Molar C:P ratios of the material ingested (solid line and circles) and material egested (dashed lines and open circles) by the different consumer groups in (a) spring and (b) summer. The gray bars indicate the C:P ratios of the organisms themselves. Note the differences in scale between spring and summer. In summer, herbivores egest material that is even more P deficient than their P-depleted food. For an explanation of organism abbreviations, see the legend to Fig. 5.

ues were produced for all winter and spring periods, i.e., in the absence of $\mathrm{P}$ depletion. In contrast, massbalance conditions for midsummer and autumn could only be fulfilled by reducing the original C-based production estimates of ciliates, rotifers, and herbivorous crustaceans by $20 \%$ unless extremely high growth efficiencies were assumed. We restricted the latter to $33 \%$ in units of C (Straile [1997] and literature cited therein), and to $80 \%$ in units of P (Hessen and Andersen 1990). Sensitivity analyses revealed that higher $\mathrm{C}$ gross growth efficiencies increased the likelihood of consumer P limitation. For example, in summer 1990 an increase in ciliate $\mathrm{C}$ production of $20 \%$ corresponded to an increase in $\mathrm{C}$ gross growth efficiency to $33-40 \%$, and required a concomitant increase in the P-retention ability to $90 \%$. Hence, assuming a maximum $\mathrm{C}$ gross growth efficiency in summer and autumn of $>33 \%$ frequently resulted in no or only slightly enlarged herbivore production due to a lack of $\mathrm{P}$. In addition, increasing the gross growth efficiencies of herbivores to $>33 \%$ was in conflict with the estimates of maximum bacterial growth efficiency during part of the investigation period. Higher gross growth efficiencies of herbivores imply lower herbivore egestion rates. This diminishes the amount of organic $\mathrm{C}$ available for bacterial growth (Fig. 8) and enlarges the bacterial growth efficiency required to achieve the measured bacterial production.

When considering growth efficiencies in units of $\mathrm{P}$, DeMott et al. (1998) measured up to $89 \%$ and Olsen et al. (1986) calculated up to $100 \% \mathrm{P}$ retention by daphnids. Our model results suggest that the maximum nutrient-retention ability plays a key role in the nutrient cycling within the food web. Maximum retention influenced the modeled level of $\mathrm{P}$ recycling, the relative and absolute importance of algal and bacterial $\mathrm{P}$ uptake, the relative share of $\mathrm{P}$ obtained by small and large consumers, and the relative and absolute importance of the microbial loop (Fig. 5). The high sensitivity of $\mathrm{P}$ egestion by heterotrophic flagellates (HF) to changes in the maximum P-retention ability may to some extent be a model artifact. We did not strictly constrain the minimum production of HF since we lacked precise measurements. Hence, the model algorithm reduced the production of HF by up to $50 \%$ if this assisted in fulfilling the other constraints.

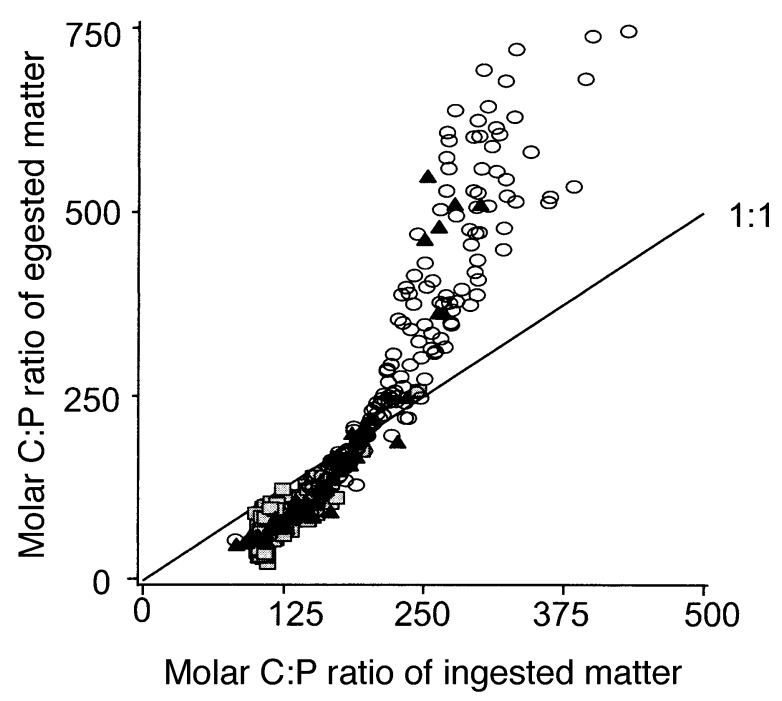

FIG. 7. Relationship between the molar C:P ratios of ingested food items and egested matter for all herbivores (open ovals), carnivorous crustaceans and fish (solid triangles), and heterotrophic flagellates (gray rectangles) during the different seasonal time intervals in 1987-1993. The line represents a $C: P$ ratio of ingested and egested material of $1: 1$. The egesta of organisms feeding on P-rich food were $\mathrm{P}$ enriched and thus fell below the line. When feeding on a P-depleted diet, organisms egested material with a high $\mathrm{C}: \mathrm{P}$ ratio located well above the line. 

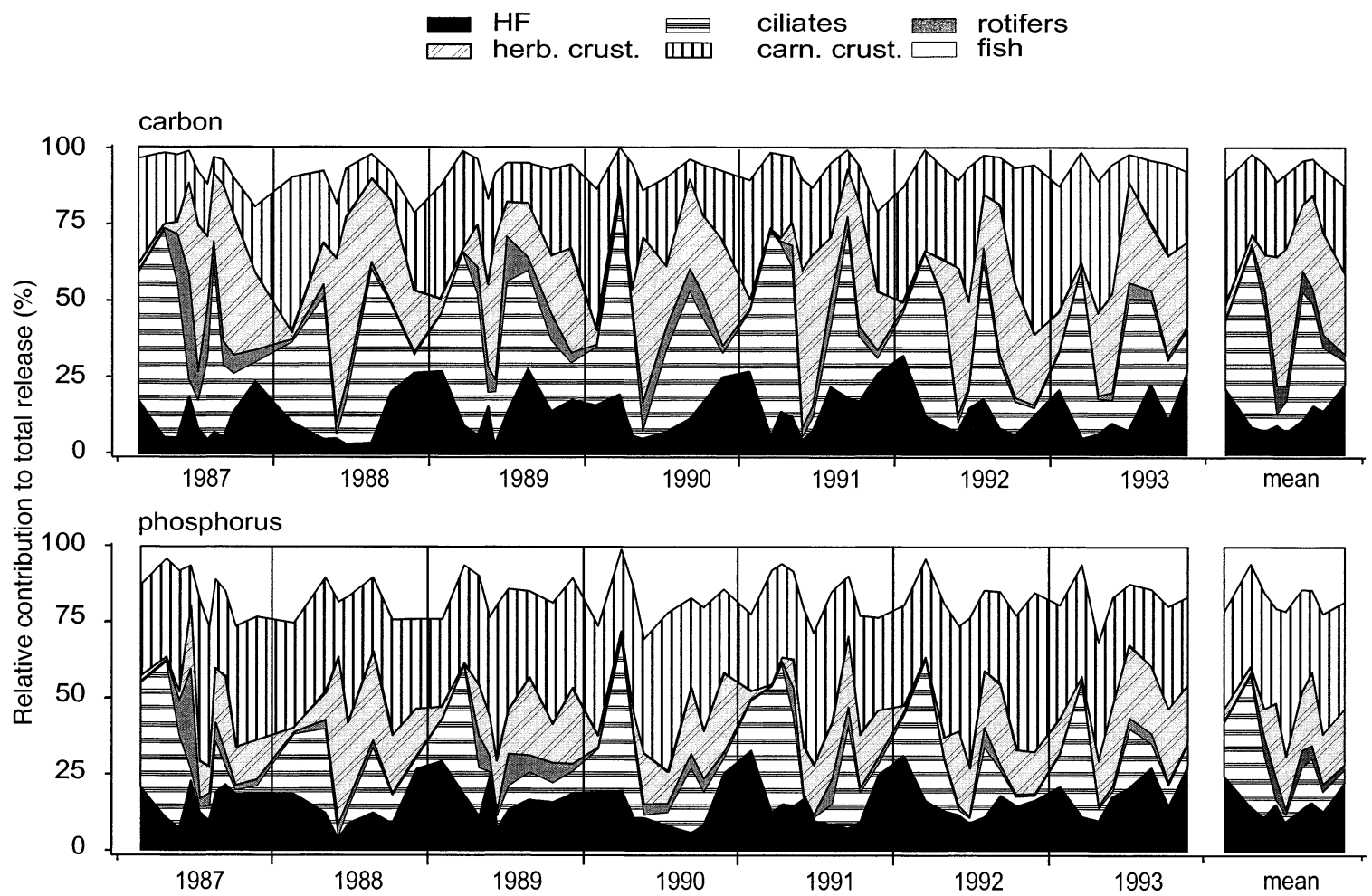

FIG. 8. Seasonal and interannual variability in the relative contribution of the pelagic consumer groups to the release of organic C (upper panel) and P remineralization (lower panel). In contrast to previous perceptions, bacterivorous flagellates and carnivores were the dominant P remineralizers particularly in the summer. In contrast, organic C was generally released by herbivores. $\mathrm{C}$ exudation by phytoplankton is omitted from the figure but not from computations. For an explanation of organism abbreviations, see the legend to Fig. 5.

Our model results depended to a great extent on the algal and bacterial $\mathrm{C}: \mathrm{P}$ ratios, since they determined the $\mathrm{P}$ input into the food web and hence potential limitations. As a consequence, they were measured in situ (Hochstädter 2000). In addition, we conducted a model sensitivity analysis by altering the $\mathrm{C}: \mathrm{P}$ ratios of algae between 130:1 and 650:1 on a mole:mole basis and those of bacteria between 50:1 and 130:1. Consistent with our expectations, increasing algal and bacterial C: $\mathrm{P}$ ratios within the model initially hardly influenced the $\mathrm{C}$ growth efficiencies of the herbivores and bacterivores. However, $\mathrm{P}$ growth efficiencies increased if they were not yet at their maximum value. If $\mathrm{P}$ growth efficiencies were at their maximum, $\mathrm{C}$ growth efficiencies and production declined.

\section{Standing stocks, production, and $C$ and $P$ fluxes}

The relative contribution of the various plankton compartments to total biomass and production varied considerably with respect to $\mathrm{C}$ and $\mathrm{P}$, owing to the pronounced differences in their nutrient content (Fig. 1). Throughout the year, $\mathrm{C}$ entered the food web predominantly via primary producers rather than via bacteria since autotrophic $\mathrm{C}$ production greatly exceeded bacterial $\mathrm{C}$ production (Fig. 2). In contrast, $\mathrm{P}$ uptake by primary producers and bacteria was of equal im- portance under P-depleted conditions (Fig. 2), although bacteria comprised only $1 / 7$ of the $C$ content of phytoplankton. This model result appears reasonable since bacterial P-uptake efficiencies per unit $\mathrm{C}$ can exceed those of algae by a factor of 6 (Jansson 1988). It also agrees with direct measurements of ${ }^{32} \mathrm{P}$ uptake in Lake Constance conducted in 1991 (Rothhaupt and Güde 1992) and several other lakes (Currie and Kalff 1984, Berman 1985, Istvánovics et al. 1990). These studies showed $50 \% \mathrm{P}$ uptake by bacteria. An equal amount of $\mathrm{P}$ uptake by autotrophs and bacteria implies that the detritus chain, which summarizes all fluxes originating from bacteria, is as important as the grazing chain, which describes all trophic links directly based on autotrophic production (cf. Fig. 3).

The ratio between bacterial and algal $P$ uptake in the model was high when the epilimnetic SRP (soluble reactive phosphorus) concentrations measured during the corresponding time interval were low and vice versa. A linear relationship between the two parameters was highly significant ( $t$ test, $P<0.0001$ ). This agrees with the superior $\mathrm{P}$ uptake abilities of bacteria at low nutrient concentrations (Suttle et al. 1990). Our model predicts an increase in the ratio between bacterial and algal $\mathrm{P}$ uptake from $\sim 1: 1$ to $\sim 2: 1$ during the ongoing reoligotrophication if molar algal $\mathrm{C}: \mathrm{P}$ ratios increase 
from 520:1 to 775:1 (assuming a constant bacterial C: $\mathrm{P}$ ratio of 100:1). Indeed, we observed such high in situ algal $\mathrm{C}: \mathrm{P}$ ratios at our sampling site on occasion in 1995 (Hochstädter 2000). However, measurement made in another part of the lake were generally lower (H. Güde, personal communication). The increase in $\mathrm{C}: \mathrm{P}$ ratios may be indirectly enforced by an improved light climate (Sterner et al. 1997) owing to lower chlorophyll concentrations and a deeper secchi depth during reoligotrophication (Gaedke 1998).

\section{Contribution of phytoplankton and bacteria to consumer $C$ and $P$ demands}

Bacteria and protozoans were the dominant contributors of $\mathrm{P}$ under $\mathrm{P}$-depleted conditions, i.e., when algal $\mathrm{C}: \mathrm{P}$ ratios exceeded those of bacteria and zooplankton by a factor of 4 to 5 (Figs. 3 and 4 ). The importance of the microbial loop for the $\mathrm{P}$ supply of herbivores has rarely been quantified, because most investigations to date have focused on the role of bacteria as a source of C for crustacean plankton (Azam et al. 1983, Porter 1996). Our study shows that labeling the suspensionfeeding zooplankton as "herbivorous" is adequate from the viewpoint of $\mathrm{C}$ and energy supply but may not be in terms of nutrient supply. Bacteria were identified as the most important source of $\mathrm{P}$ for filter-feeding crustaceans in a model study (Vadstein et al. 1993) and in Lake Kjelsasputten when evidence from laboratory feeding rates and field measurements of standing stocks were combined (Hessen and Andersen 1990). However, Lake Kjelsasputten is characterized by a much greater supply of allochthonus $\mathrm{C}$, enabling higher bacterial growth than in Lake Constance.

Carnivorous organisms preyed upon food items with an elemental composition almost identical to their own (Fig. 6). This implies that $\mathrm{C}$ and $\mathrm{P}$ growth efficiencies were of similar magnitude (30-35\%), and indicates energy limitation and an excess of nutrients. Furthermore, and in contrast to previous perceptions, in our model carnivorous crustaceans rather than herbivores were of the greatest importance for $\mathrm{P}$ remineralization under Pdepleted conditions (Figs. 3 and 8), despite assuming a maximum P-retention ability for herbivores of $80 \%$. $\mathrm{A}$ higher $\mathrm{P}$ retention would have rendered herbivores even less important for remineralization.

\section{Remineralization}

If $\mathrm{P}$ is scarce in the food relative to zooplankton demands given the available food, the animals must selectively concentrate $\mathrm{P}$ in the body tissue to maximize net production. Consequently, in summer the egesta of herbivores were more P depleted than their P-deficient diet. In contrast, the egesta of heterotrophic flagellates, carnivorous crustaceans, and fish were $\mathrm{P}$ enriched relative to their ingesta owing to the relatively high $\mathrm{P}$ content of their prey items and $\mathrm{C}$ losses by respiration (Fig. 6). The dependence of the C:P ratios of the egesta on those of the food items (Fig. 7) is in qualitative agreement with field, laboratory, and model studies on individual predator-prey interactions (Elser et al. 1988, Jürgens and Güde 1990, Sterner 1990, Urabe 1993, Gulati et al. 1995).

The increasing variability in the relative $\mathrm{P}$ content of the egesta with increasing $\mathrm{P}$ depletion of the resources (Fig. 7) originated from a higher variability in the allocation of the surplus of $\mathrm{C}$ to respiration and excretion under P-limiting conditions. $\mathrm{C}$ not used for production owing to a lack of $\mathrm{P}$ was egested and respired in the model. Egested $\mathrm{C}$ was taken up by bacteria that, in turn, respired it to a large extent, particularly under P-depleted conditions. The mathematical algorithms underlying our model (cf. Hart et al. 1997) ensure an approximately proportionate change in the respiration rates of all herbivores and bacteria and in the egested material. By these means, a reasonable balance is maintained between the various loss factors for all compartments. Under P-sufficient and C-limiting conditions, respiration was closely linked to production in the model (i.e., the $\mathrm{C}$ net gross efficiency was maximized) and the $C: P$ ratio of the egesta was tightly related to that of the diet and the body tissue of the consumers (Fig. 7). Such model behavior appears reasonable (cf. Jürgens and Güde 1990).

The range of mass-specific P-release rates within the various consumer compartments calculated by the model agrees with direct laboratory measurements (Table 3). This comparison provided an additional consistency check for the model because egestion rates were not predefined but obtained instead from the difference between ingestion and the combined losses by production and respiration. The lowest mass-specific $\mathrm{P}$-egestion rates of herbivorous crustaceans obtained with the model remained higher than the minimum values obtained in the laboratory (Table 3 ). This may originate from an extremely P-poor diet in the experiments, which would not allow sufficient growth to balance mortality in situ, and/or from an underestimation of the P-retention ability of the herbivores in the model (see Methods and model assumptions, above).

Previous studies suggested that daphnids, owing to their high $\mathrm{P}$ demands and low $\mathrm{C}: \mathrm{P}$ ratios, (1) are more likely to be $\mathrm{P}$ limited than crustaceans with higher $\mathrm{C}$ : $\mathrm{P}$ ratios (DeMott and Gulati 1999, Schulz and Sterner 1999), (2) egest less $P$, and (3) fix high amounts of $P$ in their biomass, which is subsequently no longer available to other organisms including their own prey (Elser and Urabe 1999). Hence, the elemental composition of the crustaceans and algae were interrelated in laboratory and mesocosm studies because consumers fertilize their own prey (Lyche et al. 1996). Our results support the first and second statement. However, taking an ecosystem perspective provides a different view on the availability of the $\mathrm{P}$ incorporated into daphnid biomass. In most natural systems, daphnids have a relatively high biomass turnover due to carnivores and thus a relatively high rate of remineralization of the $\mathrm{P}$ incor- 
TABLE 3. A comparison between previously documented studies and our model results for P mass-specific egestion rates by zooplankton.

\begin{tabular}{|c|c|c|c|}
\hline Organism & $\mathrm{P}$ content of food & $\begin{array}{l}\text { P release rate } \\
(\mu \mathrm{g} \mathrm{P}-\mathrm{mg} . \\
\left.\mathrm{DM}^{-1} \cdot \mathrm{h}^{-1}\right) \dagger\end{array}$ & Information source \\
\hline Paraphysomonas imperforata & $\begin{array}{l}\mathrm{P} \text { rich } \\
\mathrm{P} \text { depleted }\end{array}$ & $\begin{aligned} & 2.2-3.8 \\
< & 0.1\end{aligned}$ & Andersen et al. (1986) \\
\hline Heterotrophic flagellates & $\mathrm{P}$ rich & $2.2-5.9$ & present study \\
\hline Strombidium sulcatus (bacterivor) & $\ddagger$ & $0-24.6$ & Allali et al. (1994) \\
\hline Ciliates & $\begin{array}{l}\mathrm{P} \text { rich } \\
\mathrm{P} \text { depleted }\end{array}$ & $\begin{array}{l}10.8 \\
0.3-1.1\end{array}$ & present study \\
\hline Rotifers & $\begin{array}{l}\stackrel{+}{\mathrm{P}} \text { rich } \\
\mathrm{P} \text { depleted }\end{array}$ & $\begin{array}{l}0.1-45.0 \\
6.3 \\
0.6-1.2\end{array}$ & $\begin{array}{l}\text { Ejsmont-Karabin (1984) } \\
\text { present study }\end{array}$ \\
\hline Daphnia galeata & $\begin{array}{l}\mathrm{P} \text { rich } \\
\mathrm{P} \text { depleted }\end{array}$ & $\begin{array}{l}0.5 \\
0.07\end{array}$ & Vadstein et al. (1995) \\
\hline D. galeata & $\begin{array}{l}\mathrm{P} \text { rich } \\
\mathrm{P} \text { depleted }\end{array}$ & $\begin{array}{l}0.13 \\
0.05\end{array}$ & Gulati et al. (1995) \\
\hline Daphnia sp. & $\begin{array}{l}\mathrm{P} \text { rich } \\
\mathrm{P} \text { depleted }\end{array}$ & $\begin{array}{l}1.1-1.5 \\
0.05\end{array}$ & Olsen and Østgaard (1985) \\
\hline Daphnia galeata and Diaptomus minutus & $\mathrm{P}$ rich & $0.3-1.1$ & Peters (1975) \\
\hline Herbivorus crustaceans & $\mathrm{P}$ rich & $0.7-1.2$ & present study \\
\hline
\end{tabular}

Notes: Deviations among empirical investigations are partially attributable to the differences in the techniques employed to determine $\mathrm{P}$ (Gulati et al. 1995). Priority was given to literature values providing simultaneous information on the C:P ratios measured in P-rich and P-depleted food. In the present study, P-rich food occurred in spring and had a molar C:P ratio below 250:1. P-depleted food prevailed in summer and autumn and had a C:P ratio > 300:1. In the literature studies, the P content of the food was either specified by its C:P ratio (Gulati et al. 1995), its P content (Vadstein et al. 1995), or by the $\mathrm{P}$ concentration in the culture medium (Olsen and Østgaard 1985, Andersen et al. 1986). In all cases when it was given, we followed the author's classification of P-rich and P-depleted food.

$\dagger$ Units converted when necessary by assuming dry mass (DM) is 2.2 times the carbon content (Anderson and Hessen 1991).

$\ddagger \mathrm{P}$ content of food not specified.

porated in the daphnid biomass. This was neglected in the small-scale studies mentioned above.

When we doubled the C:P ratio of the crustaceans in our model, corresponding, e.g., to a species shift from daphnids to Bosmina (another cladoceran), we observed higher $\mathrm{P}$ egestion by herbivorous crustaceans and lower P egestion by the carnivores. Hence, overall $\mathrm{P}$ remineralization remained largely unchanged. Somewhat relieved from the competition for $\mathrm{P}$ with the crustaceans, the production of the other groups of herbivores increased, enhancing the food supply and production of the carnivorous zooplankton. To summarize, the model predicts that the higher crustacean $\mathrm{C}: \mathrm{P}$ ratios will increase total herbivorous $\mathrm{C}$ production, which will be more $\mathrm{C}$ limited. The $\mathrm{P}$ supply for autotrophs and bacteria will not be strongly altered since it is the pattern of $\mathrm{P}$ allocation and remineralization rather than its quantity that will change. This prediction depends on the assumption that, within the constraints imposed by the respective feeding modes, the $\mathrm{C}$ and $\mathrm{P}$ supplied by the algae and bacteria is allocated to the different compartments of suspension feeders in such a way that $\mathrm{C}$ and $\mathrm{P}$ deficiencies are balanced across all compartments as far as possible. That is, by species shifts and changes in individual feeding patterns the available re- sources are exploited in the best possible way within the boundaries defined by the feeding mode.

\section{Interplay between consumer $C$ and P limitation}

$\mathrm{P}$ is an essential mineral, and several studies have demonstrated lower individual and population growth rates of herbivorous crustaceans fed with P-depleted algae (Sommer 1992, Sterner 1993, Sterner et al. 1993). However, P-starved phytoplankton may also have lower concentration of essential biochemicals such as vitamins, amino acids, or fatty acids, and may develop thicker cell walls (Müller-Navarra 1995, van Donk et al. 1997), which may further lower their food quality (Anderson and Pond 2000, Wacker and von Elert 2001). This implies that the question of correlation or causation between low algal $\mathrm{P}$ content and growth reduction of herbivores requires careful consideration. Urabe et al. (1997) proved a direct causal relationship between the $\mathrm{P}$ depletion of the algae and herbivorous growth reduction in their study. Disregarding other potential limitations, the maximum $\mathrm{C}: \mathrm{P}$ ratio in the $\operatorname{diet}\left(Q_{\mathrm{C}: \mathrm{P}}^{*}\right)$ still enabling maximum $\mathrm{C}$ growth efficiencies (growth eff. $_{C}$ ) at a given $C: P$ ratio of the consumer biomass (C: $\mathrm{P}_{\text {consumer }}$ ) and a given maximum $\mathrm{P}$ growth efficiency (growth eff.p), is determined by 


$$
Q_{\mathrm{C}: \mathrm{P}}^{*}=\mathrm{C}: \mathrm{P}_{\text {consumer }} \times \text { (growth eff. }_{{ }_{\mathrm{P}}} / \text { growth eff. }_{\mathrm{C}} \text { ) }
$$

(modified according to Hessen [1992]).

$Q_{\text {C:P }}^{*}$ totalled $242(=100 \times(0.80 / 0.33))$ when using the standard assumptions underlying our study. This is in the range of values calculated in other studies with comparable assumptions for daphnids (Urabe and Watanabe 1992, Sterner 1993, 1997, Sterner and Hessen 1994, Schulz and Sterner 1999). Daphnids dominated the biomass of the suspension-feeding zooplankton $(45-80 \%)$ in Lake Constance in summer. In our case study, ciliates fed on a diet with a C:P ratio of $\sim 310$ : 1 , i.e., above $Q_{\text {C.P }}^{*}$ during summer and autumn. This indicates $\mathrm{P}$ limitation according to the theoretical considerations provided. A P deficiency was less obvious for rotifers and herbivorous crustaceans, which relied on resources with a C:P ratio of $\sim 250: 1$. Applying the model in Sterner (1997) to our case study (food quantity: $35 \mu \mathrm{mol} \mathrm{C} / \mathrm{L}$, food quality: $\mathrm{C}: \mathrm{P}=250: 1)$ we calculated P-limited growth for daphnids.

In accordance with concurrent perceptions of ecosystem organization (Ulanowicz [1999] and literature cited therein) we did not identify a single factor strongly limiting herbivorous production. We observed instead a co-limitation by food quantity and quality. Complex systems such as food webs have numerous degrees of freedom that tend to minimize the overall effect of limitations by changing their internal structure (McCann et al. [1998] and literature cited therein, cf. Falkner and Falkner 2000). As a consequence, a severe $\mathrm{P}$ deficiency may not be directly observed in situ even in strongly P-depleted systems since it is counteracted by various mechanisms (cf. Urabe and Watanabe 1993). Such mechanisms, however, do have their costs (e.g., enforced C limitation, higher predation risk), which may give rise to a trade-off between $\mathrm{P}$ limitation and other constraints. According to Brett (1993), herbivores may in principle minimize $\mathrm{P}$ limitation by:

1) increasing the $P$ growth efficiency to its maximum,

2) enhancing food consumption (compensatory feeding), and

3) selecting relatively $P$ rich food items.

The potential and consequences of the first process were analyzed above for our case study. The latter two mechanisms give rise to a complex interplay between food quantity and quality, which may yield co-limitation by $\mathrm{C}$ and $\mathrm{P}$ owing to the following causal chain, which exhibits some cross-system variability: P limitation of zooplankton is only to be expected when phytoplankton and bacteria are severely P depleted. Under such conditions, maximum autotrophic biomass and production, and hence the potential food concentration for consumers, is typically low. This lowers the potential to compensate for low food quality by high ingestion rates and restricts the maximum attainable herbivorous biomass. A relatively low grazing pressure, resulting from the resource limitation of herbivores, in turn, allows the persistence of algal cells with lower growth rates, which may then have higher $\mathrm{C}: \mathrm{P}$ ratios according to the Droop model (Droop 1983). Hence, the absolute abundance and the biochemical composition of phytoplankton are commonly closely entwined. This promotes a complex interplay between nutrient and energy limitation for predominantly herbivorous organisms under oligotrophic conditions, additional to the feedback mechanism linking grazer dynamics and algal nutritional status already described by ecological stoichiometry (Elser and Urabe 1999). Herbivorous biomass and food consumption will reach a level where resources are depleted to such a degree that $\mathrm{C}$ - and P-limited consumer growth rates are balanced by starvation and predation. This in situ linkage between the food quantity and quality of herbivores will also restrict the potential benefits of a selectivefeeding mode: disregarding potential food items with high $\mathrm{C}: \mathrm{P}$ ratios provokes a lower $\mathrm{C}$ uptake and thus may enhance energy limitation. The linkage favors omnivorous organisms, which are able to exploit a large variety of $\mathrm{C}$ and $\mathrm{P}$ sources such as bacteria, algae, and protozoans.

This line of argument is supported by our in situ results from the Lake Constance ecosystem:

a) Herbivores were roughly equally constrained by $\mathrm{C}$ and $\mathrm{P}$. Both $\mathrm{C}$ and $\mathrm{P}$ growth efficiencies were at or close to their maximum throughout the period of algal $\mathrm{P}$ depletion. The degree of $\mathrm{P}$ deficiency in the different herbivore compartments depended on the share of nonalgal food in their diet because we assumed the same $\mathrm{C}: \mathrm{P}$ ratio for each compartment of herbivores. Ciliates were the most herbivorous compartment and faced the strongest growth limitation by $\mathrm{P}$.

b) The energy supply was insufficient for maximum ciliate, rotifer, and crustacean growth (Gaedke and Straile $1994 a, b$, Straile 1998), and the C:P ratio of the food was at or slightly above $Q_{\mathrm{C}: \mathrm{P}}^{*}$.

c) Alternations in the community composition of autotrophs and herbivores during the season, as well as during reoligotrophication, allowed an enhanced exploitation of additional P sources, e.g., by an increased proportion of mixotrophic plankton obtaining $\mathrm{P}$ by bacterivory (Gaedke 1998) and of bacterivorous ciliates (Müller et al. 1991). The dominating herbivorous crustaceans, Daphnia hyalina and D. galeata, are already known to supplement their diet with non-algal food (Geller and Müller 1981), as was assumed in the model.

Details in the causal chain underlying the linkage between $\mathrm{C}$ and $\mathrm{P}$ limitation may vary in time and between systems. One reason for this complication is that the fraction of edible and digestable phytoplankton is linked to the grazing pressure (and other factors), often by time- and species-specific mechanisms. For example, during the clear-water phase in Lake Constance when the grazing pressure is at its maximum, the algal community is ruled by fast-growing, easily edible and digestible, high-quality species (Gaedke 1998). In contrast, under continuously high grazing pressure in sum- 
mer less edible or digestible species accumulate in the algal community in many (more eutrophic) systems. Hence, the mechanism leading to the interplay between energy and nutrient limitation of herbivores requires further empirical and modeling investigation.

Further evidence for consumer P deficiency in Lake Constance was obtained from feeding experiments conducted with natural and enriched seston at a station near to the institute and the island of Mainau in 1997 (i.e., $\sim 7 \mathrm{~km}$ from our pelagic sampling site) (Wacker and von Elert 2001). The experiments suggested that a $\mathrm{C}_{18}$ polyunsaturated fatty acid (alpha-linolenic acid) limited juvenile growth rates of $D$. galeata at $\mathrm{C}: \mathrm{P}_{\text {seston }}$ ratios well below $Q_{\mathrm{C}: \mathrm{P}}^{*}$, whereas at a molar $\mathrm{C}: \mathrm{P}_{\text {seston }}$ of 300:1 (i.e., above $Q_{\mathrm{C}: \mathrm{P}}^{*}$ ) a lower growth rate than expected from the concentration of the fatty acid was observed. This finding was attributed to $\mathrm{P}$ limitation (Wacker and von Elert 2001). Extrapolating these results to our $C: \mathrm{P}_{\text {seston }}$ values of 340-460:1 supports our hypothesis that $\mathrm{P}$ deficiency is relevant for herbivorous zooplankton in our sampling region during summer.

From a physiological point of view Sterner (1997) argued that food quality would be of little importance if food quantity was approaching the starvation level since the limited amount of energy from the food available is required for consumer maintenance and does not enable production of new consumer biomass, which demands P. From an ecosystem perspective, such a decoupling of food quantity and quality is unlikely to be typical for our system as the predation pressure on herbivores would frequently cause a rapid decline of nonreproducing populations (but compare Güde and Gries [1998] for selected time periods).

Our results and previous studies on ecological stoichiometry (Gulati et al. 1991, Schulz and Sterner 1999) give rise to the hypotheses that in severely P-deficient systems (1) suspension-feeding zooplankton with relatively high $\mathrm{C}: \mathrm{P}$ ratios gain importance, and (2) zooplankton with low $\mathrm{C}: \mathrm{P}$ ratios feed more strongly on non-algivorous food sources at a given algal $\mathrm{C}: \mathrm{P}$ ratio than species with lower P demands. The first hypothesis is supported by the long-term observations of crustacean abundance in Lake Constance and the literature (Elser et al. 2000). Daphnids with a molar C:P ratio in the range of 100:1 gained considerably in importance during the decades of eutrophication (Straile and Geller 1998). During recent years, daphnid abundance and their relative contribution to herbivorous crustacean biomass dropped from $\sim 80 \%$ to $60 \%$ in summer, supporting our suggestion of $\mathrm{P}$ limitation in daphnids. The next important suspension-feeding crustacean species in summer in terms of biomass is the calanoid copepod Eudiaptomus. Eudiaptomus had a C:P ratio of $\sim 350: 1$ (Hessen and Lyche 1991) and exhibited the opposite pattern. Its relative contribution to total herbivorous crustacean biomass decreased during eutrophication and then increased from $15-20 \%$ to $30 \%$ in recent years (i.e., after the present investigation period; Straile and
Geller 1998; D. Straile unpublished data). It should, however, be acknowledged that $\mathrm{P}$ demand is not the only factor influencing the competitive ability of the individual crustacean species and that the observed changes in Bosmina do not fit unambiguously into this model.

The second hypothesis concerning a relationship between the degree of omnivory and of $\mathrm{P}$ demands in nonpredatory zooplankton cannot be tested rigorously with the Lake Constance data available. Such a test should comprise numerous zooplankton taxa including ciliates and rotifers and cross-system comparisons.

\section{CONCLUSIONS}

In agreement with recent ideas about ecosystem organization we did not identify a single, strongly limiting factor. Instead, production of predominantly herbivorous plankton in Lake Constance was constrained by both $\mathrm{P}$ and $\mathrm{C}$ availability during summer and autumn. As predicted by stoichiometric theory, the extent of herbivore $\mathrm{P}$ depletion depended on their grazing of P-enriched organisms. As a consequence Protozoa improved the food quality of algae and bacteria for larger consumers not only by repacking them into larger food particles (Gaedke et al. 1996) but also by providing a more suitable chemical composition. Unexpectedly, herbivores were unambiguously ruled out as the dominant $\mathrm{P}$ remineralizers during summer and autumn, independent of the exact specification of their P-retention ability and their direct growth reduction by $\mathrm{P}$ limitation. This role was adopted by carnivores and bacterivores, which had an excess of $\mathrm{P}$ in their diet and were energy limited. The development of the multiple-commodity models was very data and time demanding but it enabled a powerful analysis of the functional dualism of zooplankton as both sink and source for $\mathrm{P}$, and of the complex and temporally changing interplay between energy and nutrient deficiency. We regard our finding that the suspension-feeding zooplankton is on the edge of $\mathrm{C}$ and $\mathrm{P}$ limitation in summer as robust against measurement errors and model artifacts. For a system being on the edge of different limiting factors may imply (1) that the most limiting factor may switch rapidly. We identified alternations in $\mathrm{C}$ and $\mathrm{P}$ limitation throughout the season, interannually, and among consumer compartments in the model. (2) A methodological implication is that the identification of the most limiting factor is difficult in both experimental and model studies, as it may depend on minor changes or uncertainties in the diet composition, $\mathrm{C}$ and $\mathrm{P}$ growth efficiencies, and elemental composition of predator and prey. In situ, even a severe $\mathrm{P}$ deficiency may not be observed directly since it is counteracted by various mechanisms.

\section{ACKNOWLEDGMENTS}

Data acquisition was performed by a large team of scientists within the Special Collaborative Program (SFB) 248 "Cycling of Matter in Lake Constance" supported by Deut- 
sche Forschungsgemeinschaft (DFG). We thank Elanor Bell, Ingrid Chorus, Eric von Elert, Hans Güde, Sandra Pauluhn, Thomas Petzoldt, Ursula Scharler, Lewi Stone, and Guntram Weithoff for stimulating comments on earlier versions of the manuscript. R. DeMott and an anonymous reviewer improved the content and style of the manuscript.

\section{Literature Cited}

Allali, K., J. Dorlan, and F. Rassoulzadegan. 1994. Culture characteristics and orthophosphate excretion of a marine oligotrich ciliate, Strombidium sulcatum, fed heat-killed bacteria. Marine Ecology Progress Series 105:159-165.

Andersen, O. K., J. C. Goldman, D. A. Caron, and M. R. Dennett. 1986. Nutrient cycling in a marine microflagellate food chain. III. Phosphorus dynamics. Marine Ecology Progress Series 31:47-55.

Andersen, T. 1997. Pelagic nutrient cycles. Herbivores as sources and sinks. Ecological Studies 129. Springer Verlag, Berlin, Germany.

Anderson, F., and D. O. Hessen. 1991. Carbon, nitrogen and phosphorus content of freshwater zooplankton. Limnology and Oceanography 36:807-814.

Anderson, T. R., and D. W. Pond. 2000. Stoichiometric theory extended to micronutrients: comparison of the roles of essential fatty acids, carbon, and nitrogen in the nutrition of marine copepods. Limnology and Oceanography 45:11621167.

Azam, F., T. Fenchel, J. G. Field, J. S. Gray, L. A. MeyerReil, and F. Thingstad. 1983. The ecological role of watercolumn microbes in the sea. Marine Ecology Progress Series 10:257-263.

Baretta, J. W., W. Ebenhöh, and P. Ruardij. 1995. The European Regional Seas Ecosystem Model, a complex marine ecosystem model. Netherlands Journal of Sea Research 33: 261-270.

Bäuerle, E., and U. Gaedke, editors. 1998. Lake Constance: characterization of an ecosystem in transition. Archiv für Hydrobiologie, Special issues: Advances in Limnology 53: $1-610$.

Berman, T. 1985. Uptake of [ $\left.{ }^{32} \mathrm{P}\right]$ orthophosphate by algae and bacteria in Lake Kinneret. Journal of Plankton Research 7: 71-84.

Brett, T. 1993. Possibility of N or P limitation for planktonic cladocerans: an experimental test (Urabe and Watanabe) and nutrient limitation of zooplankton production (Hessen). Limnology and Oceanography 38:1333-1337.

Currie, D. J., and J. Kalff. 1984. The relative importance of bacterioplankton and phytoplankton in phosphorus uptake in freshwater. Limnology and Oceanography 29:311-315.

del Giorgio, P. A., and J. J. Cole. 1998. Bacterial growth efficiency in natural aquatic systems. Annual Review of Ecology and Systematics 29:503-541.

DeMott, W. R., and D. R. Gulati. 1999. Phosphorus limitation in Daphnia: evidence from a long term study of three hypertrophic Dutch lakes. Limnology and Oceanography 44: 1557-1564.

DeMott, W. R., D. R. Gulati, and K. Siewertsen. 1998. Effects of phosphorus-deficient diets on the carbon and phosphorus balance of Daphnia magna. Limnology and Oceanography 43:1147-1161.

Droop, M. R. 1983. 25 years of algal growth kinetics. Botanica Marina 26:99-112.

Ejsmont-Karabin, J. 1984. Phosphorus and nitrogen excretion by lake zooplankton. Ecologia Polska 32:3-42.

Elser, J. J., D. R. Dobberfuhl, N. A. MacKay, and J. H. Schampel. 1996. Organism size, life history, and N:P stoichiometry. BioScience 46:674-684.

Elser, J. J., M. M. Elser, N. A. MacKay, and S. R. Carpenter. 1988. Zooplankton-mediated transitions between N- and P-limited algal growth. Limnology and Oceanography 33: $1-14$.
Elser, J. L., and R. P. Hassett. 1994. A stoichiometric analysis of the zooplankton-phytoplankton interaction in marine and freshwater systems. Nature 370:211-213.

Elser, J. J., R. W. Sterner, E. Gorokhova, W. F. Fagan, T. A. Markow, J. B. Cotner, J. F. Harrison, S. E. Hobbie, G. M. Odell, and L. J. Weider. 2000. Biological stoichiometry from genes to ecosystems. Ecology Letters 3:540-550.

Elser, J. J., and J. Urabe. 1999. The stoichiometry of consumer-driven nutrient cycling: theory, observations, and consequences. Ecology 80:735-751.

Fahnenstiel, G. L., and D. Scavia. 1987. Dynamics of Lake Michigan phytoplankton: primary production and growth. Canadian Journal of Fisheries and Aquatic Sciences 44: 499-508.

Falkner, G., and R. Falkner. 2000. Objectivistic views in biology: an obstacle to our understanding of self-organisation processes in aquatic ecosystems. Freshwater Biology 44:553-559.

Gaedke, U. 1992. Identifying ecosystem properties: a case study using plankton biomass size distributions. Ecological Modelling 63:277-298.

Gaedke, U. 1998. Functional and taxonomical properties of the phytoplankton community of large and deep Lake Constance: interannual variability and response to re-oligotrophication. Archiv für Hydrobiologie, Special issues: Advances in Limnology 53:119-141.

Gaedke, U., and D. Straile. 1994a. Seasonal changes of the quantitative importance of protozoans in a large lake. An ecosystem approach using mass-balanced carbon flow diagrams. Marine Microbial Food Webs 8:163-188.

Gaedke, U., and D. Straile. 1994b. Seasonal changes of trophic transfer efficiencies in a plankton food web derived from biomass size distributions and network analysis. Ecological Modelling 75/76:435-445.

Gaedke, U., D. Straile, and C. Pahl-Wostl. 1996. Trophic structure and carbon flow dynamics in the pelagic community of a large lake. Pages 60-71 in G. Polis and K. Winemiller, editors. Food webs: integration of patterns and dynamics. Chapman and Hall, New York, New York, USA.

Geller, W., and H. Müller. 1981. The filtration apparatus of Cladocera: filter mesh sizes and their implications of food selectivity. Oecologia 49:316-321.

Goldman, J., D. A. Caron, and M. R. Dennet. 1987. Nutrient cycling in a microflagellate food chain. 4. Phytoplanktonmicroflagellate interactions. Marine Ecology Progress Series 38:75-87.

Güde, H. 1991. Participation of bacterioplankton in epilimnetic phosphorus cycles of Lake Constance. Internationalen Vereinigung für Theoretische und Angewandte Limnologie Verhandlungen 24:816-820.

Güde, H., and T. Gries. 1998. Phosphorus fluxes in Lake Constance. Archiv für Hydrobiologie, Special issues: Advances in Limnology 53:505-544.

Güde, H., H. Rossknecht, and G. Wagner. 1998. Anthropogenic impact on the trophic state of Lake Constance during the 20th century. Archiv für Hydrobiologie, Special issues: Advances in Limnology 53:585-108.

Gulati, R. D., C. P. Martinez, and K. Siewertsen. 1995. Zooplankton as a compound mineralising and synthesizing system: phosphorus excretion. Hydrobiologia 315:25-37.

Gulati, R. D., K. Siewertsen, and L. van Liere. 1991. Carbon and phosphorus relationship of zooplankton and its seston food. Memorie dell'Istituto di Italiano Idrobiologia 48: 279-298.

Hart, D., L. Stone, A. Stern, D. Straile, and U. Gaedke. 1997. Methods for balancing ecosystem flux charts: new techniques and software. Environmental Modelling and Assessment 2:23-28.

Hennes, K., and M. Simon. 1995. Significance of bacteriophages for controlling bacterioplankton growth in a me- 
sotrophic lake. Applied Environmental Microbiology 61: 333-340.

Hessen, D. O. 1990. Carbon, nitrogen and phosphorus status in Daphnia at varying food conditions. Journal of Plankton Research 12:1239-1249.

Hessen, D. O. 1992. Nutrient element limitation of zooplankton production. American Naturalist 140:799-814.

Hessen, D. O. 1997. Stoichiometry in food webs-Lotka revisited. Oikos 79:195-200.

Hessen, D. O., and T. Andersen. 1990. Bacteria as a source of phosphorus for zooplankton. Hydrobiologia 206:217223.

Hessen, D. O., and A. Lyche. 1991. Inter- and intraspecific variations in zooplankton element composition. Archiv für Hydrobiologie 121:343-353.

Hochstädter, S. 2000. Seasonal changes of C:P-ratios of seston, bacteria, phytoplankton and zooplankton in a deep, mesotrophic lake. Freshwater Biology 44:453-464.

Istvánovics, V., K. Petterson, and D. Pierson. 1990. Partitioning of phosphate uptake between different size groups of planktonic microorganisms in Lake Erken. Internationalen Vereinigung für Theoretische und Angewandte Limnologie Verhandlungen 24:231-235.

Jansson, M. 1988. Phosphate uptake and utilization by bacteria and algae. Hydrobiologia 170:177-189.

Jürgens, K., and H. Güde. 1990. Incorporation and release of phosphorus by planktonic bacteria and phagotrophic flagellates. Marine Ecology Progress Series 59:271-284.

Klepper, O., and J. P. G. van de Kamer. 1987. The use of mass balances to test and improve the estimates of carbon fluxes in an ecosystem. Mathematical Biosciences 85:3749.

Lyche, A., T. Andersen, K. Christoffersen, D. O. Hessen, P. H. B. Hansen, and A. Klysner. 1996. Mesocosm tracer studies. 1. Zooplankton as sources and sinks in the pelagic phosphorus cycle of a mesotrophic lake. Limnology and Oceanography 41:460-474.

McCann, K., A. Hastings, and G. R. Huxel. 1998. Weak trophic interactions and the balance of nature. Nature 395 : 794-798.

Montagnes, D. J. S., D. H. Lynn, J. C. Roff, and W. D. Taylor. 1988. The annual cycle of heterotrophic planktonic ciliates in the waters surrounding the Isles of Shoals, Gulf of Maine: an assessment of their trophic role. Marine Biology 99:21-30.

Müller, H., A. Schöne, R. M. Pinto-Coelho, A. Schweizer, and T. Weisse. 1991. Seasonal succession of ciliates in Lake Constance. Microbial Ecology 21:119-138.

Müller-Navarra, D. C. 1995. Biochemical versus mineral limitation in Daphnia. Limnology and Oceanography 40: 1209-1214.

Nakano, S. I. 1994. Carbon-, nitrogen-, phosphorus ratios and nutrient regeneration of a heterotrophic flagellate fed on bacteria with different elemental ratios. Archiv für Hydrobiologie 128:257-271.

Olsen, I., A. Jensen, H. Reinertsen, A. Y. Børsheim, M. Heldal, and A. Langeland. 1986. Dependence of the rate of release of phosphorus by zooplankton on the $\mathrm{P}: \mathrm{C}$ ratio in food supply as calculated by a recycling model. Limnology and Oceanography 31:34-44.

Olsen, Y., and K. Østgaard. 1985. Estimating release rates of phosphorus from zooplankton: model and experimental verification. Limnology and Oceanography 30:844-852.

Pauli, H. R. 1991. Estimates of rotifer productivity in Lake Constance: a comparision of methods. Internationalen Vereinigung für Theoretische und Angewandte Limnologie Verhandlungen 24:850-853.

Peters, R. H. 1975. Phosphorus regeneration by natural populations from zooplankton. Internationalen Vereinigung für
Theoretische und Angewandte Limnologie Verhandlungen 19:273-279.

Porter, K. G. 1996. Integrating the microbial loop and the classic food chain into a realistic planktonic food web. Pages 51-59 in G. Polis and K. Winemiller, editors. Food webs: integration of patterns and dynamics. Chapman and Hall, New York, New York, USA.

Reiners, W. A. 1986. Complementary models for ecosystems. American Naturalist 127:59-73.

Rigler, F. H., and J. A. Downing. 1984. The calculation of secondary productivity. Pages 19-58 in J. A. Downing and F. H. Rigler, editors. Secondary productivity in fresh waters. Blackwell Scientific, Oxford, UK.

Rothhaupt, K. O., and H. Güde. 1992. The influence of spatial and temporal concentration gradients on phosphate partitioning between different size fractions of plankton: further evidence and possible causes. Limnology and Oceanography 37:739-749.

Schulz, K. L., and R. W. Sterner. 1999. Phytoplankton phosphorus limitation and food quality for Bosmina. Limnology and Oceanography 44:1549-1556.

Sommer, U. 1992. Phosphorus limited Daphnia: intraspecific facilitation instead of competition. Limnology and Oceanography 37:966-973.

Sterner, R. W. 1990. The ratio of nitrogen to phosphorus resupplied by herbivores: zooplankton and the algal competitive arena. American Naturalist 136:209-229.

Sterner, R. W. 1993. Daphnia growth on varying quality of Scenedesmus: mineral limitation of zooplankton. Ecology 74:2351-2360.

Sterner, R. W. 1997. Modelling interactions of food quality and quantity in homeostatic consumers. Freshwater Biology 38:473-481.

Sterner, R. W., J. Clasen, W. Lampert, and T. Weisse. 1998. Carbon: phosphorus stoichiometry and food chain production. Ecology Letters 1:146-150.

Sterner, R. W., J. J. Elser, E. J. Fee, S. J. Guildford, and T. H. Chrzanowski. 1997. The light: nutrient ratio in lakes: the balance of energy and materials affects ecosystem structure and process. American Naturalist 150:663-684.

Sterner, R. W., D. D. Hagemeier, W. L. Smith, and R. F. Smith. 1993. Phytoplankton nutrient limitation and food quality for Daphnia. Limnology and Oceanography 38:857-871.

Sterner, R. W., and D. O. Hessen. 1994. Algal nutrient limitation and the nutrition of aquatic herbivore. Annual Review of Ecology and Systematics 25:1-29.

Stich, H. B. 1991. Phosphorus and carbon values of zooplankton species in Lake Constance. Internationalen Vereinigung für Theoretische und Angewandte Limnologie Verhandlungen 24:837-841.

Stone, L., T. Berman, R. Bonner, S. Barry, and S. W. Weeks. 1993. Lake Kinneret: a seasonal model for carbon flux through the planktonic biota. Limnology and Oceanography 38:1680-1695.

Straile, D. 1997. Gross growth efficiencies of protozoan and metazoan zooplankton and their dependence on food concentration, predator-prey weight ratio, and taxonomic group. Limnology and Oceanography 42:1375-1385.

Straile, D. 1998. Biomass allocation and carbon flow in the pelagic food web of Lake Constance. Archiv für Hydrobiologie, Special issues: Advances in Limnology 53:545563.

Straile, D., and W. Geller. 1998. Crustacean zooplankton in Lake Constance from 1920 to 1995: response to eutrophication and re-oligotrophication. Archiv für Hydrobiologie, Special issues: Advances in Limnology 53:255-274.

Suttle, C. A., J. A. Fuhrman, and D. G. Capone. 1990. Rapid ammonium cycling and concentration-dependent partitioning of ammonium and phosphate: implications for carbon 
transfer in planktonic communities. Limnology and Oceanography 35:424-433.

Ulanowicz, R. E. 1999. Life after Newton: an ecological metaphysic. BioSystems 50:127-142.

Ulanowicz, R. E., and D. Baird. 1999. Nutrient controls on ecosystem dynamics: the Chesapeake mesohaline community. Journal of Marine Systems 19:159-172.

Ulanowicz, R. E., and J. J. Kay. 1991. A package for the analysis of ecosystem flow networks. Environmental Software 6:131-142.

Urabe, J. 1993. N and P cycling coupled by grazers' activities: food quality and nutrient release by zooplankton. Ecology 74:2337-2350.

Urabe, J., J. Clasen, and R. W. Sterner. 1997. Phosphorus limitation of Daphnia growth: is it real? Limnology and Oceanography 42:1436-1443.

Urabe, J., and Y. Watanabe. 1992. Possibility of N or P limitation for planktonic cladocerans: an experimental test. Limnology and Oceanography 37:244-251.

Urabe, J., and Y. Watanabe. 1993. Implications of sestonic elemental ratio in zooplankton ecology. Reply to the com- ment by Brett. Limnology and Oceanography 38:13371340.

Vadstein, O., O. Brekke, T. Andersen, and Y. Olsen. 1995. Estimations of phosphorus release rates from natural zooplankton communities feeding on planktonic algae and bacteria. Limnology and Oceanography 40:250-262.

Vadstein, O., Y. Olsen, and H. Reinertsen. 1993. The role of planktonic bacteria in phosphorus cycling in lakes-sink or link? Limnology and Oceanography 38:1539-1544.

van Donk, E., M. Lürling, D. O. Hessen, and G. M. Lokhorst. 1997. Altered cell wall morphology in nutrient-deficient phytoplankton and its impact on grazers. Limnology and Oceanography 42:357-364.

Wacker, A., and E. von Elert. 2001. Polyunsaturated fatty acids: evidence for non-substitutable biochemical resources in Daphnia galeata. Ecology 82:2507-2520.

Weisse, T., and H. Müller. 1998. Planktonic Protozoa and the microbial food web in Lake Constance. Archiv für Hydrobiologie, Special issues: Advances in Limnology 53:223254.

Wulff, F., F. G. Field, and K. H. Mann, editors. 1990. Network analysis in marine ecology. Springer-Verlag, New York, New York, USA. 